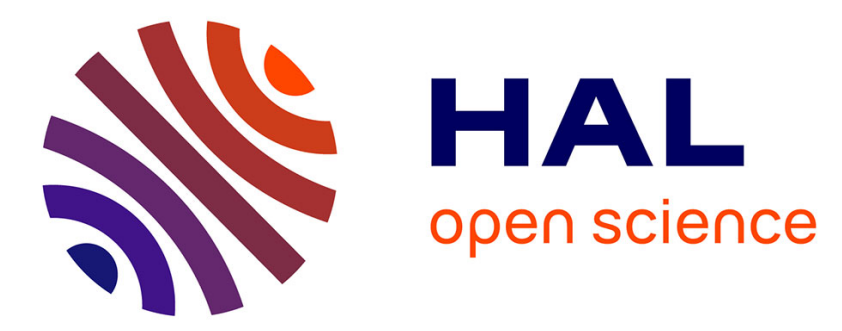

\title{
Compositional and pressure controls on calcium and magnesium isotope fractionation in magmatic systems
}

Chunfei Chen, Jin-Xiang Huang, Stephen Foley, Zaicong Wang, Frédéric Moynier, Yongsheng Liu, Wei Dai, Ming Li

\section{- To cite this version:}

Chunfei Chen, Jin-Xiang Huang, Stephen Foley, Zaicong Wang, Frédéric Moynier, et al.. Compositional and pressure controls on calcium and magnesium isotope fractionation in magmatic systems. Geochimica et Cosmochimica Acta, 2020, 290, pp.257-270. 10.1016/j.gca.2020.09.006 . insu03029807

\section{HAL Id: insu-03029807 https://hal-insu.archives-ouvertes.fr/insu-03029807}

Submitted on 29 Nov 2020

HAL is a multi-disciplinary open access archive for the deposit and dissemination of scientific research documents, whether they are published or not. The documents may come from teaching and research institutions in France or abroad, or from public or private research centers.
L'archive ouverte pluridisciplinaire HAL, est destinée au dépôt et à la diffusion de documents scientifiques de niveau recherche, publiés ou non, émanant des établissements d'enseignement et de recherche français ou étrangers, des laboratoires publics ou privés. 


\section{Journal Pre-proofs}

Compositional and pressure controls on calcium and magnesium isotope fractionation in magmatic systems

Chunfei Chen, Jin-Xiang Huang, Stephen F. Foley, Zaicong Wang, Frédéric Moynier, Yongsheng Liu, Wei Dai, Ming Li

PII: S0016-7037(20)30557-3

DOI: https://doi.org/10.1016/j.gca.2020.09.006

Reference: GCA 11912

To appear in:

Geochimica et Cosmochimica Acta

Received Date:

11 December 2019

Revised Date:

14 August 2020

Accepted Date:

7 September 2020

Please cite this article as: Chen, C., Huang, J-X., Foley, S.F., Wang, Z., Moynier, F., Liu, Y., Dai, W., Li, M., Compositional and pressure controls on calcium and magnesium isotope fractionation in magmatic systems, Geochimica et Cosmochimica Acta (2020), doi: https://doi.org/10.1016/j.gca.2020.09.006

This is a PDF file of an article that has undergone enhancements after acceptance, such as the addition of a cover page and metadata, and formatting for readability, but it is not yet the definitive version of record. This version will undergo additional copyediting, typesetting and review before it is published in its final form, but we are providing this version to give early visibility of the article. Please note that, during the production process, errors may be discovered which could affect the content, and all legal disclaimers that apply to the journal pertain.

(C) 2020 Elsevier Ltd. All rights reserved. 


\title{
Compositional and pressure controls on calcium and magnesium isotope fractionation in magmatic systems
}

\author{
Chunfei Chen ${ }^{\mathrm{a}, \mathrm{b}^{*}}$, Jin-Xiang Huang ${ }^{\mathrm{a}}$, Stephen F. Foley ${ }^{\mathrm{a}}$, Zaicong Wang ${ }^{\mathrm{b}}$, Frédéric \\ Moynier ${ }^{\mathrm{c}}$, Yongsheng Liu ${ }^{\mathrm{b}}$, Wei Dai ${ }^{\mathrm{b}}$, and Ming $\mathrm{Li}^{\mathrm{b}}$ \\ ${ }^{a} A R C$ Centre of Excellence for Core to Crust Fluid Systems, Dept. of Earth and Environmental \\ Sciences, Macquarie University, North Ryde, New South Wales 2109, Australia \\ ${ }^{b}$ State Key Laboratory of Geological Processes and Mineral Resources, School of Earth Sciences, \\ China University of Geosciences, Wuhan 430074, China \\ ${ }^{c}$ Institut de Physique du Globe de Paris, Université de Paris,1 rue Jussieu, 75005 Paris, France
}

\section{*Corresponding author}

Chunfei Chen, chfchen2016@hotmail.com and Yongsheng Liu,yshliu@hotmail.com

\begin{abstract}
:
Stable isotope fractionation in magmatic systems depends on equilibrium isotope fractionation between different phases. However, current equilibrium stable isotope theory mostly assumes ideal crystal structures and simple chemical compositions, but it is unclear how the pressure and complex compositional variations in natural microscopic mineral structures affect inter-mineral stable isotope fractionation and thus control stable isotope fractionation in macroscopic magmatic systems. Here, we calculate the $\mathrm{Ca}-\mathrm{O}$ and $\mathrm{Mg}-\mathrm{O}$ bond lengths controlled by pressure and compositional variations of coexisting garnet (Grt) and clinopyroxene (Cpx) in the Roberts Victor eclogites from the Kaapvaal Craton and use these data as a proof of concept to interpret their inter-mineral $\mathrm{Ca}$ and $\mathrm{Mg}$ isotopic compositions $\left(\Delta^{44 / 40} \mathrm{Ca}_{\mathrm{Grt}-\mathrm{Cpx}}\right.$ and $\left.\Delta^{26} \mathrm{Mg}_{\mathrm{Grt}-\mathrm{Cpx}}\right)$. Our results show that the $\mathrm{Ca}-\mathrm{O}$ difference between Grt and $\mathrm{Cpx}\left(\Delta \mathrm{Ca}-\mathrm{O}_{\mathrm{Grt}-\mathrm{Cpx}}\right)$ shows a significant increase with $\mathrm{CaO}$ content from 3.4 to $13.6 \mathrm{wt} . \%$ in $\mathrm{Grt}$ and with pressure from 2.9 to $6.9 \mathrm{GPa} . \Delta \mathrm{Ca}-\mathrm{O}_{\mathrm{Grt}-\mathrm{Cpx}}$ has an excellent negative correlation with inter-mineral $\mathrm{Ca}$ isotope fractionation corrected for temperature effect $\left(\Delta^{44 / 40} \mathrm{Ca}_{\mathrm{Grt}-\mathrm{Cpx}} \times \mathrm{T}^{2} / 10^{6}\right)$, indicating that inter-mineral Ca isotope fractionation is controlled by pressure and compositional variations of the Grt through effects on the bond
\end{abstract}


lengths. Inter-mineral $\mathrm{Mg}$ isotope fractionation corrected for temperature effect $\left(\Delta^{26} \mathrm{Mg}_{\mathrm{Grt}-\mathrm{Cpx}} \times\right.$ $\mathrm{T}^{2} / 10^{6}$ ) in these eclogites shows a negative correlation with pressure but no obvious correlations with the mineral compositions, suggesting the dominant role of pressure effect in addition to temperature. The Mg-O bond length of Grt increases by about $0.02 \AA$ with increasing $\mathrm{CaO}$ content in Grt of these eclogites, implying a mild compositional effect on inter-mineral $\mathrm{Mg}$ isotope fractionation. The results suggest that pressure and compositional variations in minerals control the equilibrium stable isotope fractionation between minerals. Utilizing the $\mathrm{Ca}$ isotope fractionation factor controlled by crystal chemistry of garnet, our modelling indicates that partial melting of eclogite in the mantle could not significantly fractionate $\mathrm{Ca}$ isotopes and, therefore, that low $\delta^{44 / 40} \mathrm{Ca}$ values in previously reported basalts cannot be attributed to the involvement of eclogite in their sources. This suggests that crystal chemistry exerts major controls on isotope fractionation in magmatic systems in addition to temperature.

Keywords: stable isotopes, pressure, compositional variations, eclogites, magmatic systems

\section{Introduction}

The stable isotopes of major elements such as $\mathrm{Fe}, \mathrm{Si}, \mathrm{Mg}$ and $\mathrm{Ca}$ have been widely used to understand the origin and evolution of terrestrial planets and to trace crust-mantle recycling (e.g., Bourdon et al., 2018; Chen et al., 2018; Huang et al., 2011; Huang and Jacobsen, 2017; Valdes et al., 2014). The stable isotope geochemistry of magmatic processes during the formation and evolution of terrestrial planets is controlled by equilibrium stable isotope fractionation among different phases. To quantitatively interpret isotopic data, the equilibrium stable isotope fractionation factors between phases must be known and this has been the focus of a multitude of studies in the last twenty years (e.g., Schauble, 2004; Young et al., 2015). Equilibrium isotope fractionation factors have been primarily determined by theoretical modelling that calculates isotope fractionation between minerals with ideal crystal structures and simple chemical compositions (Huang et al., 2013; Schauble, 2011), which have shown that temperature and chemical bond lengths exert the major control on the distribution of the isotopes, with heavy isotopes tending to be concentrated in minerals with shorter bonds (e.g., Schauble, 2004). 
Although some recent calculations predicted significant effects for $\mathrm{CaO}$ and $\mathrm{K}_{2} \mathrm{O}$ contents on inter-mineral stable isotope fractionation of $\mathrm{Ca}$ and $\mathrm{K}$ isotopes, respectively (Antonelli et al., 2019; Feng et al., 2014; Li et al., 2019; Wang et al., 2017a; Wang et al., 2017b), modelling results cannot easily explain large and variable isotope differences between minerals in natural samples (Antonelli et al., 2019; Liu et al., 2011; Wang et al., 2017b). A possible reason is that natural minerals have complex chemical compositions and that bond lengths are controlled by chemical compositions and pressure (Nestola et al., 2008; Novak and Gibbs, 1971; Yang and Ghose, 1995). Very few theoretical models have investigated the effect of pressure (Huang et al., 2013) or the combined effect of pressure and chemical compositions on equilibrium isotope fractionation factors. It is unclear how the pressure and compositional variations in natural microscopic mineral structures affect the equilibrium stable isotope fractionation between minerals and thus control the stable isotope geochemistry of macroscopic magmatic systems.

The ideal pathway for the investigation of inter-mineral equilibrium isotope fractionation is the direct measurement of isotope differences between minerals in natural samples with a range of equilibrium temperatures (and/or pressures) and chemical compositions, provided that equilibrium between the minerals can be demonstrated. These isotopic data can be compared to bond lengths that are controlled by pressure and compositional variations. Here we present $\mathrm{Ca}$ isotopic measurements for garnet (Grt) and clinopyroxene (Cpx) with variable chemical compositions separated from a series of well-characterized eclogite xenoliths from the Kaapvaal craton (Gréau et al., 2011; Huang et al., 2016; Huang et al., 2012), and combine them with previously reported $\mathrm{Mg}$ isotope measurements (Huang et al., 2016). We calculate the $\mathrm{Ca}-\mathrm{O}$ and $\mathrm{Mg}-\mathrm{O}$ bond lengths of the Grt and Cpx in these eclogites and establish their relationship to inter-mineral stable isotope fractionation. Finally, we investigate how pressure and compositional variations control stable isotope fractionation in magmatic processes.

\section{Roberts Victor eclogites}

The eclogite samples are xenoliths from the Roberts Victor kimberlite (128 $\pm 15 \mathrm{Ma}$ in age (Smith et al., 1985)) in the central Kaapvaal craton (Fig. S1), in which most xenoliths are eclogites ( $\sim 80 \%$ ) (Macgregor and Carter, 1970). Previous studies have identified two distinct groups 
(including five sub-groups) based on microstructure and geochemical compositions (Gréau et al., 2011; Huang et al., 2016; Huang et al., 2012; Macgregor and Carter, 1970; McCandless and Gurney, 1989; Schulze et al., 2000). The first group (Type I) have been interpreted as metasomatised eclogites containing subhedral or rounded Grt in a Cpx matrix. They show highly enriched incompatible element patterns and have Grt with high $\mathrm{Na}_{2} \mathrm{O}(\geq 0.07$ wt.\%) and Cpx with high $\mathrm{K}_{2} \mathrm{O}$ ( $\geq 0.08$ wt.\%). The second group (Type II) are primary eclogites with interlocking textures of anhedral Grt and Cpx. They show depleted incompatible element patterns, indicating that pristine Type II eclogites escaped mantle metasomatism. We estimate their equilibrium temperatures and pressures using the garnet-clinopyroxene Fe-Mg geothermometer of Krogh (1988) projected on to the local conductive geothermal gradient (Chapman and Pollack, 1977) with $40 \mathrm{~mW} / \mathrm{m}^{2}$ surface heat flow (Griffin et al., 2003). On the basis of equilibrium temperature and pressure, we can divide the eclogites into low-temperature and pressure eclogites (Low-TP, 810-910 ${ }^{\circ} \mathrm{C}$ and 2.9-3.5 GPa) and high temperature and pressure eclogites (High-TP, $>1050{ }^{\circ} \mathrm{C}$ and 4.4-6.9 GPa) (Table 1). The samples selected for $\mathrm{Ca}$ isotopic analysis in the present study include ten Type I eclogites (all High-TP eclogites) and ten Type II eclogites including five High-TP and five Low-TP eclogites.

\section{Methods}

\subsection{Sample preparation}

Clear and fresh Grt and Cpx were separated under a binocular microscope after processing the hand specimen by SelFrag (electrostatic disaggregation). In order to remove any possible Ca carbonate on the mineral surfaces, handpicked minerals were rinsed in milli-Q water and leached in $1 \mathrm{~mol} / \mathrm{L} \mathrm{HCl}$ at room temperature before digestion. About 5-20 $\mathrm{mg}$ of mineral grains were dissolved using $3 \mathrm{ml} \mathrm{HF}+1 \mathrm{ml} \mathrm{HNO}_{3}$ in $7 \mathrm{ml}$ Teflon vessels on a hotplate $\left(120{ }^{\circ} \mathrm{C}\right)$, followed by the replenishment of the dried residue with $1 \mathrm{ml} \mathrm{HNO}_{3}+1 \mathrm{ml} \mathrm{HCl}$ until the solutions were clear. Finally, samples were dried and re-dissolved in $1 \mathrm{ml} 4 \mathrm{~mol} / \mathrm{L} \mathrm{HNO}_{3}$ for chemical purification.

\subsection{Calcium isotope analysis}

Chemical purification and measurement of $\mathrm{Ca}$ isotopes were performed at the State Key Laboratory of Geological Processes and Mineral Resources, China University of Geosciences, 
Wuhan, China. The detailed column chemistry and measurements by MC-ICP-MS (multi-collector inductively-coupled-plasma mass-spectrometer) have been documented in previous publications (Chen et al., 2020; Chen et al., 2019; Feng et al., 2018; Li et al., 2018); here we provide a short summary. Calcium was separated from the sample matrix on micro-columns filled with Ca-selective DGA resin: unlike $\mathrm{Ca}$, matrix elements such as $\mathrm{Al}, \mathrm{Fe}, \mathrm{K}, \mathrm{Ti}, \mathrm{Na}, \mathrm{Sr}$, and $\mathrm{Mg}$ are not retained on DGA resin in $4 \mathrm{~mol} \mathrm{l}^{-1} \mathrm{HNO}_{3}$. The Ca fraction was collected in $3 \mathrm{ml} \mathrm{H}_{2} \mathrm{O}$. High recovery ( $>99 \%$ ), efficient separation of $\mathrm{Ca}$ and a low total procedural blank of $<10 \mathrm{ng}$ were achieved. Calcium isotopic measurements were performed using a Nu Plasma 1700 MC-ICP-MS. The ${ }^{42} \mathrm{Ca},{ }^{43} \mathrm{Ca}$ and ${ }^{44} \mathrm{Ca}$ ion beams were measured using Faraday cups at $\mathrm{L} 4, \mathrm{~L} 2$, and $\mathrm{H} 2$. Isotope measurements were performed using standard-sample bracketing to correct for instrumental drift over time. Calcium isotopic variations are defined using $\delta$-notation: $\delta^{\mathrm{n} / 42} \mathrm{Ca}=$ $\left[\left({ }^{\mathrm{n}} \mathrm{Ca} /{ }^{42} \mathrm{Ca}\right)_{\text {sample }} /\left({ }^{\mathrm{n}} \mathrm{Ca} /{ }^{42} \mathrm{Ca}\right)_{\text {SRM915a }}-1\right] \times 1000$ where $\mathrm{n}=44$ or 43 . All $\mathrm{Ca}$ isotopic values $\left(\delta^{44 / 42} \mathrm{Ca}\right)$ in this study are converted to $\delta^{44 / 40} \mathrm{Ca}$ using a factor of 2.048 calculated by the mass-dependent fractionation law (Heuser et al., 2016). Two standard deviations of $\delta^{44 / 40} \mathrm{Ca}$ of NIST SRM 915b measured in the course of previous studies over one year were 0.14\%o $(n=62)$ (Chen et al., 2019; Li et al., 2018), which represents the long-term external precision for this study.

Four reference materials (BIR-1, BCR-2, BHVO-2, and OKUM) and seven duplicate samples were processed as unknowns to assess accuracy and reproducibility. We obtained $\delta^{44 / 40} \mathrm{Ca}$ of 0.80 $\pm 0.07 \%$ o (2sd, $n=4), 0.81 \pm 0.10 \%$ o (2sd, $n=8), 0.80 \pm 0.08 \%$ o (2sd, $n=7)$ and $0.86 \pm 0.03 \%$ o (2sd, $\mathrm{n}=2$ ) for BIR-1, BCR-2, BHVO-2, and OKUM respectively (Table S1), consistent with previous studies within the analytical uncertainty (Amini et al., 2009; Amsellem et al., 2017; Feng et al., 2017; He et al., 2017; Liu et al., 2017b; Schiller et al., 2012). Seven duplicate samples show good reproducibility within the analytical uncertainty (Table 1$)$. A three-isotope plot $\left(\delta^{43 / 42} \mathrm{Ca}\right.$ versus $\delta^{44 / 42} \mathrm{Ca}$ ) is commonly used for identifying mass-independent fractionation, isobaric interference, and analytical artefacts. All measured $\delta^{44 / 42} \mathrm{Ca}$ and $\delta^{43 / 42} \mathrm{Ca}$ of Grt and $\mathrm{Cpx}$ in the eclogites and the reference materials plot on a line of theoretical kinetic fractionation with a slope of 0.506 (Heuser et al., 2016) (Fig. S2), suggesting no analytical artifacts from interferences.

\subsection{Calculation of $\mathrm{Ca}-\mathrm{O}$ and $\mathrm{Mg}-\mathrm{O}$ bond lengths of garnet and clinopyroxene}

In Grt $\left(\mathrm{X}_{3} \mathrm{Y}_{2} \mathrm{Si}_{3} \mathrm{O}_{12}\right), \mathrm{X}$ and $\mathrm{Y}$ cations occupy polyhedra with dodecahedral and octahedral coordination with $\mathrm{O}$, respectively. Cations such as $\mathrm{Ca}^{2+}, \mathrm{Mg}^{2+}$, and $\mathrm{Fe}^{2+}$ preferentially occupy the 
eight-fold coordinated $\mathrm{X}$ site while $\mathrm{Al}^{3+}$ and $\mathrm{Fe}^{3+}$ cations prefer the six-fold coordinated $\mathrm{Y}$ site $\left(\mathrm{Ca}_{\mathrm{x}}, \mathrm{Mg}_{\mathrm{y}}, \mathrm{Fe}^{2+}{ }_{3-\mathrm{x}-\mathrm{y}}\right)\left(\mathrm{Fe}^{3+}{ }_{\mathrm{z}}, \mathrm{Al}_{2-\mathrm{z}}\right) \mathrm{Si}_{3} \mathrm{O}_{12}$ (Wang, 1973). The substitution of $\mathrm{Al}^{3+}$ by $\mathrm{Fe}^{3+}$ in the $\mathrm{Y}$ site does not significantly change $\mathrm{X}-\mathrm{O}$ bond length in Grt (Novak and Gibbs, 1971) and the $\mathrm{Fe}^{3+}$ content in eclogitic Grt is low, so this is not considered further in this study. As the ionic radius of $\mathrm{Ca}^{2+}(1.14 \AA)$ is much larger than those of $\mathrm{Mg}^{2+}$ and $\mathrm{Fe}^{2+}(0.86 \AA$ and $0.77 \AA$, respectively) (Shannon, 1976), the proportion of $\mathrm{Ca}^{2+}$ in the $\mathrm{X}$ site may largely control X-O bond length. In addition, $\mathrm{Mg}^{2+}$ and $\mathrm{Fe}^{2+}$ have similar radii, implying that the variation of $\mathrm{Fe}^{2+}$ content in the $\mathrm{X}$ site does not significantly modify the X-O bond length (Novak and Gibbs, 1971). Therefore, we would not consider the effect of the $\mathrm{Fe}^{2+}$ on the bond lengths. Previous ab initio calculations of the pyrope $\left(\mathrm{Mg}_{3} \mathrm{Al}_{2} \mathrm{Si}_{3} \mathrm{O}_{12}\right)$-grossular $\left(\mathrm{Ca}_{3} \mathrm{Al}_{2} \mathrm{Si}_{3} \mathrm{O}_{12}\right)$ solid solutions series at $1 \mathrm{~atm}$ indicated that the $\mathrm{Ca}-\mathrm{O}$ and $\mathrm{Mg}-\mathrm{O}$ bond lengths of the Grt increase almost linearly from $2.35 \AA$ to $2.39 \AA$ and 2.28 $\AA$ to $2.31 \AA$, respectively, with $\mathrm{Ca}$ afu $\left(\mathrm{x}_{\mathrm{Ca}}\right.$ ) increasing from 0.12 to 1.5 in the $\mathrm{X}$ site (Fig. 1a) (Freeman et al., 2006). We estimate the $\mathrm{Ca}-\mathrm{O}$ and $\mathrm{Mg}-\mathrm{O}$ bond lengths of Grt in the Roberts Victor eclogites at $1 \mathrm{~atm}(\mathrm{~L}[\mathrm{Ca}-\mathrm{O}](1 \mathrm{~atm})$ and $\mathrm{L}[\mathrm{Mg}-\mathrm{O}](1 \mathrm{~atm}))$ by projecting $\mathrm{x}_{\mathrm{Ca}}$ of Grt onto the bond lines in Fig. 1a.

In $\mathrm{Cpx}\left(\mathrm{XYSi}_{2} \mathrm{O}_{6}\right)$, large cations such as $\mathrm{Ca}^{2+}$ and $\mathrm{Na}^{+}$preferentially occupy the eight-fold coordinated $\mathrm{X}$ site while smaller cations (e.g., $\mathrm{Mg}^{2+}, \mathrm{Fe}^{2+}, \mathrm{Fe}^{3+}$, and $\mathrm{Al}^{3+}$ ) prefer the six-fold coordinated Y site. The variation of the Ca-O bond length in $\mathrm{Cpx}\left(\left(\mathrm{Ca}_{\mathrm{x}} \mathrm{Na}_{1-\mathrm{x}}\right)\left(\mathrm{Mg}_{\mathrm{y}}(\mathrm{Fe}, \mathrm{Al})_{1-\mathrm{y}}\right)\right.$ $\mathrm{Si}_{2} \mathrm{O}_{6}$ ) is limited: the average $\mathrm{Ca}-\mathrm{O}$ bond length increases from $2.458 \AA$ to $2.470 \AA$ with increasing $\mathrm{x} / \mathrm{y}$ from $3 / 4$ to 1 and decreases from $2.470 \AA$ to $2.453 \AA$ with increasing $\mathrm{x} / \mathrm{y}$ from 1 to $5 / 4$ (Wang et al., 2017b). Furthermore, the effect of $\mathrm{Na}$ content on the average $\mathrm{Ca}-\mathrm{O}$ bond length is also limited: the average bond length decreases by less than $0.01 \AA$ as the jadeite proportion increases from 0 to $53 \%$ at a given pressure (Nestola et al., 2008). Variation in Cpx compositions in the Roberts Victor eclogites corresponds to a formula of $\left(\mathrm{Ca}_{0.51-0.70} \mathrm{Na}_{0.18-0.40} \mathrm{Fe}_{0.05-0.15}\right)\left(\mathrm{Mg}_{0.41-0.80}(\mathrm{Fe}, \mathrm{Al})_{0.20-0.59}\right) \mathrm{Si}_{2} \mathrm{O}_{6}$, indicating that the average Ca-O bond length is about 2.450 at $1 \mathrm{~atm} . \mathrm{Mg}^{2+}, \mathrm{Fe}^{2+}, \mathrm{Fe}^{3+}$, and $\mathrm{Al}^{3+}$ share the same $\mathrm{Y}$ site in the $\mathrm{Cpx}$. Due to the poor quantitative constraints on the effect of substitution between $\mathrm{Fe}^{2+}, \mathrm{Fe}^{3+}, \mathrm{Al}^{3+}$, and $\mathrm{Mg}^{2+}$ on $\mathrm{Mg}-\mathrm{O}$ bond length in $\mathrm{Cpx}$, we do not calculate the Mg-O bond lengths of the $\mathrm{Cpx}$ in the Roberts Victor eclogites.

With increasing pressure, the unit cell volumes and $\mathrm{Ca}-\mathrm{O}$ bond lengths of both Grt and $\mathrm{Cpx}$ 
decrease significantly. However, the rate of decrease of the $\mathrm{Ca}-\mathrm{O}$ bond length in $\mathrm{Cpx}$ is larger than that in Grt (Fig. 1b). Both first principles calculations (Walker et al., 2008) and experimental studies (Levien and Prewitt, 1981) indicate that the Ca-O bond length of diopside decreases almost linearly at a rate of $0.0092-0.0089 \AA$ per GPa (Fig. 1b). Furthermore, previous experiments (Nestola et al., 2008) indicated that the Ca-O bond lengths in jadeite $\left(\mathrm{NaAlSi}_{2} \mathrm{O}_{6}\right)$-hedenbergite $\left(\mathrm{CaFeSi}_{2} \mathrm{O}_{6}\right)$ solid solutions decrease at a similar rate of about $0.0089 \AA$ per $\mathrm{GPa}$, which is independent of their compositions. For Grt, the ab initio calculation of the structural properties of grossular $\left(\mathrm{Ca}_{3} \mathrm{Al}_{2} \mathrm{Si}_{3} \mathrm{O}_{12}\right)$ under pressure indicated that its $\mathrm{Ca}-\mathrm{O}$ bond length decreases almost linearly at a rate of $0.0049 \AA$ per GPa (Akhmatskaya et al., 1999), identical to the experimental studies of andradite $\left(0.0048 \AA\right.$ per GPa for $\left.\mathrm{Ca}_{3} \mathrm{Fe}_{2} \mathrm{Si}_{3} \mathrm{O}_{12}\right)$ (Fig. 1b) (Hazen and Finger, 1989). Hazen and Finger (1978) also indicated that the Ca-O bond length in grossular decreases at an average rate of $0.0040 \AA$ per GPa but their result indicated that the bond length does not linearly decrease with increasing pressure (Fig. 1b). Therefore, we can calculate the average $\mathrm{Ca}-\mathrm{O}$ bond lengths of the Grt and $\mathrm{Cpx}$ at their equilibration pressures (P GPa):

$$
\begin{aligned}
& \mathrm{L}[\mathrm{Ca}-\mathrm{O}](\mathrm{P} \mathrm{GPa})=\mathrm{L}[\mathrm{Ca}-\mathrm{O}](1 \mathrm{~atm})-0.0048 \times \mathrm{P} \text { for } \mathrm{Grt} \\
& \mathrm{L}[\mathrm{Ca}-\mathrm{O}](\mathrm{P} \mathrm{GPa})=\mathrm{L}[\mathrm{Ca}-\mathrm{O}](1 \mathrm{~atm})-0.0089 \times \mathrm{P} \text { for } \mathrm{Cpx}
\end{aligned}
$$

\section{Results}

Calcium isotope compositions of Grt and Cpx in the Roberts Victor eclogites are reported in Table 1 and illustrated in Fig. 2. Major element compositions of these Grt and Cpx were reported in Gréau et al. (2011) and Huang et al. (2014). The garnet separates in the Low-TP eclogites show higher $\delta^{44 / 40} \mathrm{Ca}$ values (0.80 to $1.74 \%$ ) than co-existing $\mathrm{Cpx}$ (-0.19 to $1.01 \%$ ) with $\Delta{ }^{44 / 40} \mathrm{Ca}$ Grt-Cpx values of 0.73 to $1.13 \%$. The Grt separates in the High-TP eclogites also show higher $\delta^{44 / 40} \mathrm{Ca}$ values ( 0.89 to $1.35 \%$ ) than co-existing Cpx ( 0.66 to $1.04 \%$ ) except for two samples. The Grt in the two samples show lower $\delta^{44 / 40} \mathrm{Ca}$ values (0.99 to $1.02 \%$ ) than co-existing $\mathrm{Cpx}$ (1.14 to $1.33 \%$ ). The Low-TP eclogites have much higher $\Delta^{44 / 40} \mathrm{Ca}_{\mathrm{Grt}-\mathrm{Cpx}}$ values than the High-T eclogites (-0.31\%o to $0.55 \%$ ) (Fig. 3). Furthermore, the $\Delta^{44 / 40} \mathrm{Ca}_{\mathrm{Grt}-\mathrm{Cpx}}$ values in both Low-TP and High-TP eclogites show excellent correlations with $\mathrm{CaO}$ contents of the Grt (Fig. 4). As for previously reported other eclogite xenoliths from the Kaapvaal craton (Wang et al., 2015; Wang et al., 2012), 
$\delta^{26} \mathrm{Mg}_{\mathrm{Grt}}$ in the Roberts Victor eclogites show a positive correlation with $\delta^{26} \mathrm{Mg}_{\mathrm{Cpx}}$ (Fig. 3b), and their $\Delta^{26} \mathrm{Mg}_{\text {Grt-Cpx }}$ values show a variation from -0.76 to $-0.36 \%$ (Huang et al., 2016) (Fig. 3 and Table 1).

The garnets in the Roberts Victor eclogites have variable compositions with a formula of $\left(\mathrm{Ca}_{0.27-1.09}, \mathrm{Mg}_{0.82-1.71}, \mathrm{Fe}_{0.86-1.25}\right)\left(\mathrm{Al}_{1.88-1.98} \mathrm{Fe}^{3+}{ }_{0.02-0.12}\right) \mathrm{Si}_{3} \mathrm{O}_{12}$ : their $\mathrm{Ca}$ contents are projected onto the lines of the $\mathrm{Ca}-\mathrm{O}$ and $\mathrm{Mg}-\mathrm{O}$ bond lengths in Fig. 1a for calculated $\mathrm{Ca}-\mathrm{O}$ and $\mathrm{Mg}-\mathrm{O}$ bond lengths at $1 \mathrm{~atm}$. The calculated $\mathrm{Ca}-\mathrm{O}$ and $\mathrm{Mg}-\mathrm{O}$ bond lengths for Grt in the eclogites at $1 \mathrm{~atm}$ vary from 2.355 to $2.380 \AA$ and 2.28 to $2.30 \AA$, respectively. The Ca-O bond length of the $\mathrm{Cpx}$ in the eclogites are about $2.450 \AA$ at $1 \mathrm{~atm}$, independent of their chemical compositions. The $\mathrm{Ca}-\mathrm{O}$ bond length difference between $\mathrm{Grt}$ and $\mathrm{Cpx}\left(\Delta \mathrm{Ca}-\mathrm{O}_{\mathrm{Grt}-\mathrm{Cpx}}\right)$ at $1 \mathrm{~atm}$ increases from -0.10 to -0.07 $\AA ̊$ as $\mathrm{CaO}$ content in Grt increases from 3.4 to 13.6 wt.\% (Fig. 5a). The calculated $\mathrm{Ca}-\mathrm{O}$ bond lengths for the Grt and $\mathrm{Cpx}$ in the eclogites at their equilibration pressures vary from 2.33 to 2.35 $\AA$ and 2.39 to $2.42 \AA$, respectively. $\Delta \mathrm{Ca}-\mathrm{O}_{\mathrm{Grt}-\mathrm{Cpx}}$ at their equilibration pressures varies from -0.08 to $-0.04 \AA \AA$ (Fig. 5a).

\section{Discussion}

\subsection{Isotope equilibrium in the Roberts Victor eclogites}

Chemical and isotope equilibrium between Grt and Cpx is the premise that their isotope differences reflect inter-mineral isotope equilibrium fractionation. The Roberts Victor eclogites in this study show highly variable $\Delta^{44 / 40} \mathrm{Ca}_{\mathrm{Grt}-\mathrm{Cpx}}$ values (-0.31 to $1.13 \%$ ) and uniform $\Delta^{26} \mathrm{Mg}_{\mathrm{Grt}-\mathrm{Cpx}}$ values (mostly from -0.68 to $-0.45 \%$ ). Here, we demonstrate that such $\mathrm{Ca}$ and $\mathrm{Mg}$ isotope differences between Grt and Cpx reflect inter-mineral equilibrium isotope fractionation rather than kinetic fractionation as found recently in metamorphic Grt (Antonelli et al., 2019). Firstly, mineral major and trace element compositions of the Grt and Cpx pairs from the Roberts Victor eclogites studied here have achieved chemical equilibrium. The Grt and Cpx have homogeneous chemical compositions with no mineral zoning nor chemical variations across individual samples (Gréau et al., 2011). The major elements $\mathrm{SiO}_{2}, \mathrm{Cr}_{2} \mathrm{O}_{3}$, and $\mathrm{MgO}$ show positive correlations between Grt and Cpx (Fig. 6), indicating major element equilibrium. Furthermore, the estimated equilibrium temperatures of these eclogites by the REE-in-garnet-clinopyroxene thermobarometer are in good 
agreement with the temperatures calculated by the garnet-clinopyroxene $\mathrm{Fe}-\mathrm{Mg}$ thermometer (Sun and Liang, 2015), indicating that Grt and coexisting Cpx are in equilibrium in trace elements. Given that isotope equilibrium is achieved faster than chemical equilibrium (Lesher, 1990; van der Laan et al., 1994), chemical equilibrium in the Grt and Cpx pairs indicates that the Roberts Victor eclogites will have reached inter-mineral stable isotope equilibrium. Secondly, the preservation of kinetic isotope fractionation in natural samples requires rapid cooling after a disequilibrium geological event $\left(<10^{4}\right.$ years at mantle conditions (Zhao et al., 2017)) to avoid isotope re-equilibration between minerals at high temperature. Depleted incompatible element patterns and unradiogenic $\mathrm{Sr}$ and radiogenic Nd-Hf isotopic compositions suggested that Type II eclogites, which have highly variable $\Delta^{44 / 40} \mathrm{Ca}_{\text {Grt-Cpx }}$ values, were not modified by metasomatism just before being brought to the surface by kimberlites (Gréau et al., 2011; Huang et al., 2012). Furthermore, the Type I and II eclogites have been stored in the cratonic mantle for at least $128 \mathrm{Ma}$ and $1.1 \mathrm{Ga}$, respectively (Huang et al., 2012), which is sufficient time to achieve isotope re-equilibration if kinetic fractionation occurred during formation and evolution. Lastly, kinetic isotope fractionation is caused by light isotopes generally diffusing faster than heavier isotopes and should occur simultaneously for different stable isotope systems (Teng et al., 2011; Zhao et al., 2017). No correlation between $\Delta^{44 / 40} \mathrm{Ca}_{\mathrm{Grt}-\mathrm{Cpx}}$ and $\Delta^{26} \mathrm{Mg}_{\mathrm{Grt}-\mathrm{Cpx}}$ values is seen in the Roberts Victor eclogites (Fig. 3a), therefore precluding kinetic isotope fractionation. Similar to the previously reported eclogite and garnet pyroxenite xenoliths with equilibrium inter-mineral $\mathrm{Mg}$ isotopes from Kaapvaal craton (Wang et al., 2015; Wang et al., 2012) and Hawaii (Stracke et al., 2018), the Roberts Victor eclogites in this study show a positive correlation between $\delta^{26} \mathrm{Mg}_{\mathrm{Grt}}$ and $\delta^{26} \mathrm{Mg}_{\mathrm{Cpx}}$ and fall on inter-mineral Mg equilibrium fractionation lines corresponding to the calculated result at the temperature of $850-1350^{\circ} \mathrm{C}$ and pressure of 3.0-7.0 GPa from Huang et al. (2013) (Fig. 3b), indicating equilibrium inter-mineral $\mathrm{Mg}$ isotope equilibrium in the Roberts Victor eclogites. These lines of evidence unambiguously indicate that Grt and Cpx pairs from the Roberts Victor eclogites have reached inter-mineral stable isotope equilibrium.

\subsection{Bond length variation controlled by composition and pressure}

Constraining the bond length difference between minerals is essential for understanding inter-mineral isotope equilibrium fractionation. Our bond length calculations show the $\mathrm{Ca}-\mathrm{O}$ and $\mathrm{Mg}-\mathrm{O}$ bond lengths at $1 \mathrm{~atm}$ for Grt in the Roberts Victor eclogites increase from 2.35 to $2.38 \AA$ 
and 2.28 to $2.30 \AA$, respectively, with increasing $\mathrm{CaO}$ content in the Grt from 3.4 to 13.6 wt.\% (Fig. 1a). Given the limited variation of $\mathrm{Ca}-\mathrm{O}$ bond length of the $\mathrm{Cpx}$ in the Roberts Victor eclogites at $1 \mathrm{~atm}$ with the variation of their chemical compositions, $\Delta \mathrm{Ca}-\mathrm{O}_{\mathrm{Grt}-\mathrm{Cpx}}$ at $1 \mathrm{~atm}$ shows a linear increase with $\mathrm{CaO}$ content in the $\mathrm{Grt}$, indicating the control of $\mathrm{CaO}$ content in $\mathrm{Grt}$ on the $\Delta \mathrm{Ca}-\mathrm{O}_{\mathrm{Grt}-\mathrm{Cpx}}$ (Fig. 5a). Furthermore, the variation of $\Delta \mathrm{Ca}-\mathrm{O}_{\mathrm{Grt}-\mathrm{Cpx}}$ at the equilibration pressures for these eclogites is greater than that of $\Delta \mathrm{Ca}-\mathrm{O}_{\mathrm{Grt}-\mathrm{Cpx}}$ at $1 \mathrm{~atm}$, suggesting the effect of equilibration pressure (Fig. 5a). This could be attributed to a larger decrease of $\mathrm{Ca}-\mathrm{O}$ bond length in $\mathrm{Cpx}$ as pressure increases than for Grt (Fig. 1b). Our results show that the $\mathrm{CaO}$ content of Grt and pressure exert the major controls on the $\mathrm{Ca}-\mathrm{O}$ bond length variations in $\mathrm{Grt}$ and $\mathrm{Cpx}$, and thus on inter-mineral $\mathrm{Ca}$ isotope fractionation, as discussed below.

\subsection{Isotope fractionation controlled by temperature, pressure, and compositional}

\section{variations}

Inter-mineral equilibrium isotope fractionation is controlled by temperature and basic crystal chemical parameters such as bond strength (Huang et al., 2019; Urey, 1947; Young et al., 2015). The equilibrium constant of isotopic exchange reactions between two minerals $A$ and $B\left(\alpha_{A-B}\right)$ can be written as (Young et al., 2015):

$$
\ln \alpha_{\mathrm{A}-\mathrm{B}}=\frac{1}{24}\left(\frac{h}{k_{b} T}\right)^{2}\left(\frac{1}{m}-\frac{1}{m^{\prime}}\right)\left[\frac{\widehat{K}_{f, A}}{4 \pi^{2}}-\frac{\widehat{K}_{f, B}}{4 \pi^{2}}\right]
$$

where $\mathrm{h}$ is the Planck constant, $\mathrm{k}_{\mathrm{b}}$ is the Boltzmann's constant, $\mathrm{T}$ is the temperature, $\mathrm{m}$ and $\mathrm{m}$ ' are atomic masses of light and heavy isotopes, respectively, and $\widehat{K}_{f}$ is the average force constant for the vibrational modes. This suggests that inter-mineral equilibrium isotope fractionation depends on the inverse of the square of temperature, the difference in mass between the two isotopes, and on differences in force constants for the vibrational modes in each phase (Young et al., 2015). A phase with shorter, stronger bonds has higher vibrational energy than a phase with longer bonds, and is therefore enriched in the heavier isotope (Schauble, 2004; Young et al., 2015). This implies that inter-mineral equilibrium $\mathrm{Ca}$ isotope fractionation between $\mathrm{Grt}$ and $\mathrm{Cpx}$ is a linear function of $1 / \mathrm{T}^{2}$ if the differences in force constants do not change:

$$
\Delta^{44 / 40} \mathrm{Ca}_{\mathrm{Grt}-\mathrm{Cpx}}=10^{3} \ln \alpha_{\mathrm{Grt}-\mathrm{Cpx}}^{44 / 40} \sim \frac{10^{3}}{24}\left(\frac{1}{T^{2}}\right)\left(\frac{1}{m_{40}}-\frac{1}{m_{44}}\right) .
$$

The Grt separates from the Roberts Victor eclogites show higher $\delta^{44 / 40} \mathrm{Ca}$ values ( 0.80 to 
1.74\%o) than co-existing Cpx (-0.19 to 1.04\%o), except for two High-TP eclogites (Table 1). The $\Delta^{44 / 40} \mathrm{Ca}_{\text {Grt-Cpx }}$ values of the Low-TP eclogites $(0.73$ to $1.13 \%$ ) are higher than those of the High-TP eclogites (-0.31 to $0.55 \%$ ), indicating an effect of temperature and pressure (Fig. 4a). Given the linear relationship between $1 / \mathrm{T}^{2}$ and $\Delta^{44 / 40} \mathrm{Ca}_{\mathrm{Grt}-\mathrm{Cpx}}$, we use $\mathrm{T}^{44 / 40} \mathrm{Ca}_{\mathrm{Grt}-\mathrm{Cpx}}=$ $\Delta^{44 / 40} \mathrm{Ca}_{\text {Grt-Cpx }} \times \mathrm{T}^{2} / 10^{6}$ to correct for the temperature effect. An excellent negative correlation is observed between $\mathrm{T}^{44 / 40} \mathrm{Ca}_{\mathrm{Grt}-\mathrm{Cpx}}$ and $\Delta \mathrm{Ca}-\mathrm{O}_{\text {Grt-Cpx }}$ (Fig. 5b) in the Roberts Victor eclogites, suggesting the control of bond strength on inter-mineral $\mathrm{Ca}$ isotope fractionation in addition to temperature. The excellent negative correlation between $\mathrm{T}^{44 / 40} \mathrm{Ca}_{\mathrm{Grt}-\mathrm{Cpx}}$ and $\Delta \mathrm{Ca}-\mathrm{O}_{\mathrm{Grt}-\mathrm{Cpx}}$ indicates the propensity of heavy isotopes to concentrate where force constants are greater, and therefore in stiffer bonds (usually shorter bond lengths). Interestingly, the Grts have the same $\delta^{44 / 40} \mathrm{Ca}$ as $\mathrm{Cpx}$ when $\Delta \mathrm{Ca}-\mathrm{O}_{\mathrm{Grt}-\mathrm{Cpx}}$ is about $-0.05 \AA$ (Fig. $5 \mathrm{~b}$ ), implying that Grt and Cpx have similar force constants or $\mathrm{Ca}-\mathrm{O}$ bond stiffness at the $\Delta \mathrm{Ca}-\mathrm{O}_{\mathrm{Grt}-\mathrm{Cpx}}$ of $-0.05 \AA$.

As discussed in Section 5.2, the variation of $\Delta \mathrm{Ca}-\mathrm{O}_{\mathrm{Grt}-\mathrm{Cpx}}$ depends on pressure and $\mathrm{CaO}$ content in Grt, suggesting that pressure and compositional variation significantly modify equilibrium $\mathrm{Ca}$ isotope fractionation between Grt and $\mathrm{Cpx}$. The corrected $\mathrm{T}^{44 / 40} \mathrm{Ca}_{\mathrm{Grt}-\mathrm{Cpx}}$ for the Low-TP Roberts Victor eclogites are still systematically higher than those of the High-TP eclogites, pointing to a pressure effect (Fig. 4b). We estimate the equilibrium isotope fractionation factors between Grt and $\mathrm{Cpx}$ for Grt with 5 wt.\% $\mathrm{CaO}$ at $3 \mathrm{GPa}$ and $4.5 \mathrm{GPa}$, based on the $\Delta^{44 / 40} \mathrm{Ca}_{\text {Grt-Cpx }}$ of low-T and high-T eclogites, to be (Fig. 7):

$$
\begin{aligned}
& \Delta^{44 / 40} \mathrm{Ca}_{\mathrm{Grt}-\mathrm{Cpx}}=0.96 \times 10^{6} / \mathrm{T}^{2}(\text { at } 3 \mathrm{GPa}) \\
& \left.\Delta^{44 / 40} \mathrm{Ca}_{\mathrm{Grt}-\mathrm{Cpx}}=0.66 \times 10^{6} / \mathrm{T}^{2} \text { (at } 4.5 \mathrm{GPa}\right)
\end{aligned}
$$

The difference in slope between equations 5 and 6 may indicate the control of pressure (Fig. 7). Here, we attribute the pressure effect to the difference of variation of $\mathrm{Ca}-\mathrm{O}$ bond lengths in Grt and Cpx with pressure (Fig. 1b). Due to a larger rate of decrease of the $\mathrm{Ca}-\mathrm{O}$ bond length in $\mathrm{Cpx}$ than that in Grt with increasing pressure (Fig. 1b), the $\Delta \mathrm{Ca}-\mathrm{O}_{\mathrm{Grt}-\mathrm{Cpx}}$ at $4.5 \mathrm{GPa}$ is larger than that at $3 \mathrm{GPa}$ and thus $\Delta^{44 / 40} \mathrm{Ca}_{\mathrm{Grt}-\mathrm{Cpx}}$ at $4.5 \mathrm{GPa}$ is smaller than at $3 \mathrm{GPa}$ for a given temperature.

One of the most remarkable findings is that both Low-TP eclogites and High-TP eclogites show good correlations between $\Delta^{44 / 40} \mathrm{Ca}_{\mathrm{Grt}-\mathrm{Cpx}}$ (and temperature-corrected $\mathrm{T}^{44 / 40} \mathrm{Ca}_{\mathrm{Grt}-\mathrm{Cpx}}$ ) and the $\mathrm{CaO}$ content of Grt (Fig. 4) but do not correlate with temperature or Cpx composition (Figs. S3-4), indicating a strong compositional effect on the isotopic fractionation in Grt. Our bond length 
calculations suggest that $\mathrm{Ca}-\mathrm{O}$ bond length in $\mathrm{Grt}$ at $1 \mathrm{~atm}$ is positively correlated with $\mathrm{CaO}$ content for both Low-TP and High-TP eclogites, and increases from 2.355 to $2.38 \AA$ (Fig. 1a). Given the limited variation in Ca-O bond length of $\mathrm{Cpx}$ in the Low-TP and High-TP eclogites, the increase of $\mathrm{Ca}-\mathrm{O}$ bond length in Grt results in a decrease in the difference in $\mathrm{Ca}-\mathrm{O}$ bond lengths between Grt and Cpx (Fig. 1a). This could explain the negative correlation between $\Delta{ }^{44 / 40} \mathrm{Ca}_{\text {Grt-Cpx }}$ and $\mathrm{CaO}$ content of Grt. A similar correlation between temperature effect-corrected $\Delta^{44 / 40} \mathrm{Ca}_{\mathrm{Grt}-\mathrm{Cpx}}$ values and $\mathrm{CaO}$ content of Grt was also observed in low-temperature $\left(479-872{ }^{\circ} \mathrm{C}\right)$ Dabie eclogites and peridotites (Fig. 4b) (Wang et al., 2019). The absence of a correlation between $\Delta^{44 / 40} \mathrm{Ca}_{\text {Grt-Cpx }}$ values and $\mathrm{Cpx}$ composition (e.g., jadeite proportion and $\mathrm{CaO}$ content in Cpx, Fig. S4) in both Low-TP and High-TP eclogites suggests that inter-mineral Ca isotope fractionation is not affected by the jadeite component in Cpx speculated by Wang et al. (2019), which also agrees well with the limited variation of $\mathrm{Ca}-\mathrm{O}$ bond lengths with increasing $\mathrm{Jd}$ and $\mathrm{CaO}$ content in these Cpx. We estimate the equilibrium isotope fractionation factor between Grt and Cpx for Grt with 12.7 wt. $\% \mathrm{CaO}$ at $\sim 3 \mathrm{GPa}$ (Fig. 7):

$$
\Delta^{44 / 40} \mathrm{Ca}_{\mathrm{Grt}-\mathrm{Cpx}}=0.45 \times 10^{6} / \mathrm{T}^{2}(\text { at } 3 \mathrm{GPa})
$$

The difference in slope between equations 5 and 7 may be controlled by $\mathrm{CaO}$ content in Grt (Fig. 7). Furthermore, the temperature-corrected $\mathrm{T}^{44 / 40} \mathrm{Ca}_{\mathrm{Grt}-\mathrm{Cpx}}$ in the High-TP eclogites shows a more significant decrease with increasing $\mathrm{CaO}$ in Grt (the slope of -0.13) than that of the Low-TP eclogites (the slope of -0.089) (Fig. 4b). The Low-TP eclogites show similar equilibrium pressure, whereas the equilibrium pressure of the High-TP eclogites ranges from 4.4 to $6.9 \mathrm{GPa}$ (Table 1), indicating that the slope difference in Fig. $4 \mathrm{~b}$ is most likely due to the additional pressure effect on the inter-mineral $\mathrm{Ca}$ isotope fractionation in the High-TP eclogites in addition to the compositional effect (Fig. 7).

The positive trend between $\mathrm{T}^{44 / 40} \mathrm{Ca}_{\text {Grt-Cpx }}$ and $\mathrm{T}^{26} \mathrm{Mg}_{\text {Grt-Cpx }}\left(=\Delta^{26} \mathrm{Mg}_{\mathrm{Grt}-\mathrm{Cpx}} \times \mathrm{T}^{2} / 10^{6}\right)$ indicates that, like $\mathrm{Ca}$ isotopes, inter-mineral $\mathrm{Mg}$ isotope fractionation in the Roberts Victor eclogites is also modified by pressure and/or compositional variation in addition to temperature (Fig. 8a). The negative trend between $\mathrm{T}^{26} \mathrm{Mg}_{\mathrm{Grt}-\mathrm{Cpx}}$ and pressure in the Roberts Victor eclogites and previously reported eclogite xenoliths from Kaapvaal craton (Wang et al., 2015; Wang et al., 2012) (Fig. 8b) may indicates the pressure effect on inter-mineral $\mathrm{Mg}$ isotope fractionation, consistent with the trend predicted by theoretical calculations (Huang et al., 2013). Our calculations show that the 
Mg-O bond length of Grt in the Roberts Victor eclogites increases by about $0.02 \AA$ with increasing $\mathrm{CaO}$ content in the Grt (Fig. 1a), implying a mild compositional effect on inter-mineral $\mathrm{Mg}$ isotope fractionation. However, no obvious correlation between $\mathrm{T}^{26} \mathrm{Mg}_{\mathrm{Grt}-\mathrm{Cpx}}$ and $\mathrm{CaO}$ content in Grt or Cpx compositions is found (Fig. S5). A possible reason is that any such compositional effect is much less than the pressure effect or the $\mathrm{Mg}-\mathrm{O}$ bond length of $\mathrm{Cpx}$ could also be slightly modified by their compositional variations.

An increasing number of first-principles calculations have been used to investigate the effect of the compositional variation (especially for large ionic radius elements such as $\mathrm{Ca}^{2+}$ and $\mathrm{K}^{+}$) on inter-mineral stable isotope fractionation (Antonelli et al., 2019; Li et al., 2019; Wang et al., 2017a; Wang et al., 2017b). Wang et al. (2017b) and Antonelli et al. (2019) indicated that $\Delta^{44 / 40} \mathrm{Ca}_{\mathrm{Opx}-\mathrm{Cpx}}$ decreases from 0.45 to $0.10 \%$ as $\mathrm{Ca} /(\mathrm{Ca}+\mathrm{Mg})$ in Opx ranges from $2 / 16$ to $1 / 64$ at $800-1100{ }^{\circ} \mathrm{C}$. However, these calculated results cannot easily explain large and variable isotope differences between minerals in natural samples, such as $-0.48 \%$ o to $1.25 \%$ for $\Delta^{44 / 40} \mathrm{Ca}_{\text {Opx-Cpx }}$ for mantle peridotites (Chen et al., 2019; Huang et al., 2010; Kang et al., 2016; Zhao et al., 2017). This could be attributed to (1) isotopic disequilibrium between natural minerals (Antonelli et al., 2019; Chen et al., 2018); (2) compositional differences between natural minerals and theoretical calculation; (3) the poorly investigated effect of pressure in most first-principles calculations. Interestingly, the Opx in natural peridotites with high $\Delta^{44 / 40} \mathrm{Ca}_{\mathrm{Opx}-\mathrm{Cpx}}(>0.5 \%$ ) have extremely low $\mathrm{Ca} / \mathrm{Mg}$ ratios (0.0082-0.010), lower than 1/64 (Chen et al., 2019; Huang et al., 2010; Kang et al., 2016), which has not been investigated in previous first-principles calculations (Antonelli et al., 2019; Wang et al., 2017b). This study presents a comprehensive investigation of the effect of the pressure and compositional variation on the bond length, and thus equilibrium stable isotopes, highlighting that both pressure and compositional variation could modify inter-mineral isotope fractionation (Fig. 7). The combined effect of pressure and chemical composition may help to explain inter-mineral $\mathrm{Ca}$ isotope differences in some natural spinel peridotites. Antonelli et al. (2019) indicated that the effect of $\mathrm{Ca}$ concentration is significant on $\Delta^{44 / 40} \mathrm{Ca}_{\text {Grt -Diopside }}$ (from $0.56 \%$ to $0.33 \%$ ) from pyrope with $\mathrm{Ca} / \mathrm{Mg}$ of $1 / 23$ to grossular at $850{ }^{\circ} \mathrm{C}$ and $1 \mathrm{~atm}$. However, the calculated result is smaller than for the natural eclogites in this study, for which $\Delta^{44 / 40} \mathrm{Ca}_{\text {Grt-Cpx }}$ decreases from about $0.76 \%$ to $0.36 \%$ as $\mathrm{CaO}$ content in Grt increases from 5.0 to 12.7 wt.\% at 850 and $3 \mathrm{GPa}$ (Fig. 7). This is probably attributable to the ideal crystal structures and simple mineral compositions and/or the 
poorly investigated effect of pressure in first-principles calculations. In addition, the calculations of Huang et al. (2019) predicted $0.44 \%$ for $\Delta \Delta^{44 / 40} \mathrm{Ca}_{\text {Grossular-Diopside }}$ at $850{ }^{\circ} \mathrm{C}$ and $1 \mathrm{~atm}$, higher than that of Antonelli et al. (2019) (0.33\%) (Fig. 7). Given the limited and inconsistent theoretical data on $\mathrm{Ca}$ isotope fractionation between $\mathrm{Grt}$ and $\mathrm{Cpx}$, more theoretical work in the future may provide a clearer and more comprehensive picture for the compositional and pressure effects on inter-mineral $\mathrm{Ca}$ isotope fractionation.

\subsection{The control of stable isotope geochemistry in magmatic systems}

Stable isotope variation during partial melting and magmatic differentiation depends on isotope fractionation between minerals. The present study suggests that pressure and compositional variation in minerals significantly affect isotope fractionation between minerals, indicating that the stable isotope geochemistry of magmatic systems is controlled by pressure and compositional variation in minerals. In the following section, we explore how garnet crystal chemistry controls $\mathrm{Ca}$ isotope fractionation during partial melting of eclogite, which could provide important insights into the petrogenesis of the basalts.

The involvement of eclogite in the source of basalts has been invoked to explain much lower $\delta^{44 / 40} \mathrm{Ca}$ values in basalts (as low as $0.65 \%$ ) than that of the mantle $(0.94 \pm 0.10 \%$, 2 sd, Chen et al., 2019; Kang et al., 2017) because partial melting of eclogite was speculated to significantly fractionate $\mathrm{Ca}$ isotopes in previous studies (Dai et al., 2020; Kang et al., 2019; Wang et al., 2019). The speculated $\mathrm{Ca}$ isotope fractionation during partial melting of eclogite originated from significant inter-mineral Ca isotope fractionation between Grt and Cpx. Due to poor constraints on equilibrium stable isotope mechanism, the isotope fractionation factor between Grt and Cpx has been assumed to be constant (Kang et al., 2019) or was speculated to be controlled by the Jd content of Cpx (Wang et al., 2019) in previous calculations. Utilizing our new knowledge that the

$\mathrm{Ca}$ isotope fractionation between Grt and Cpx is controlled by pressure and compositional variation of garnet, we revisit $\mathrm{Ca}$ isotope fractionation during partial melting of eclogite and modify previous interpretations about the low $\delta^{44 / 40} \mathrm{Ca}$ values of basalts. We quantitatively modelled the behaviour of $\mathrm{Ca}$ isotopes during partial melting of eclogite using an incremental batch melting model in which the fractionation factors between melt and residue were recalculated at each step (Williams and Bizimis, 2014; Zhang et al., 2018). Details are given in supplementary 
information and Table S2. Since there is no measurable calcium isotopic fractionation during the crystallization of Kilauea Iki basalts, the Ca isotopic fractionation factor between Cpx and basaltic melt $\left(\alpha_{\text {Cpx-melt }}\right)$ was suggested to be close to 1 at about 1 atm (Zhang et al., 2018). Furthermore, the MORB-like Ca isotope compositions of cumulate websterites and spinel clinopyroxenites at high-pressure ( $>1.2 \mathrm{GPa}$ and $<3 \mathrm{GPa}$ ) from the Balmuccia peridotite massif in the Italian Alps suggested that $\alpha_{\text {Cpx-melt }}$ is close to 1 at high pressure (Chen et al., 2019). Therefore, we speculate that there is no significant variation in $\alpha_{\text {Cpx-melt }}$ with increasing pressure. $\alpha_{\text {Cpx-melt }}$ is taken to be 1 in this modelling calculations and the $\alpha_{\text {Grt-melt }}$ is estimated from inter-mineral isotope fractionation between Grt and Cpx from this study. According to the high temperature $\left(>1050{ }^{\circ} \mathrm{C}\right)$ and pressure (>3 GPa) (Klemme et al., 2002) melting conditions and isotope fractionation factors controlled by compositional variation, the isotope fractionation factors between Grt and Cpx for the modelling calculation should be a function of $\mathrm{CaO}$ content of the residual $\mathrm{Grt}$ and can be estimated from $\Delta^{44 / 40} \mathrm{Ca}_{\text {Grt-Cpx }}$ of the High-TP eclogites in this study (Fig. 3a). In order to compare with previous results, we also modelled $\mathrm{Ca}$ isotope fractionation during partial melting of eclogite using the constant isotope fractionation factor from $\Delta^{44 / 40} \mathrm{Ca}_{\mathrm{Grt}-\mathrm{Cpx}}$ of the eclogites from the central Siberian craton in Kang et al. (2019) (Fig. 9). Our modelled results indicate a negligible Ca isotope difference between melts and residual eclogites using isotope fractionation factors controlled by compositional variation in garnet (Fig. 9). This contracts with the results using the assumption from previous studies that low $\delta^{44 / 40} \mathrm{Ca}$ values occur in the melts. This indicates that partial melting of eclogite could not induce significant $\mathrm{Ca}$ isotope fractionation, consistent with mantle-like $\delta^{44 / 40} \mathrm{Ca}$ of $0.90 \pm 0.04 \%$ for OIB basalts whose source involves eclogites (Valdes et al., 2014). Therefore, our study indicates that low $\delta^{44 / 40} \mathrm{Ca}$ values in basalts do not reflect the involvement of eclogite in their sources but may instead be the result of the recycling of crustal carbonates into the mantle (Amsellem et al., 2020; Huang et al., 2011; Liu et al., 2017a). These observations suggest that pressure and compositional variation in mineral structures at the microscopic scale exert major controls on $\mathrm{Ca}$ isotope fractionation in macroscopic magmatic systems which is of critical importance to understand the origin and evolution of terrestrial planets using stable isotope data. 


\section{Conclusions}

In order to investigate the effect of pressure and compositional variations in natural microscopic mineral structures on the stable isotope fractionation of macroscopic magmatic systems, this study presents inter-mineral $\mathrm{Ca}$ and $\mathrm{Mg}$ isotopic fractionation $\left(\Delta^{44 / 40} \mathrm{Ca}_{\text {Grt-Cpx }}\right.$ and $\left.\Delta^{26} \mathrm{Mg}_{\mathrm{Grt}-\mathrm{Cpx}}\right)$ of garnet and clinopyroxene from a series of well-characterized Roberts Victor eclogites from the Kaapvaal craton and calculates the $\mathrm{Ca}-\mathrm{O}$ and $\mathrm{Mg}-\mathrm{O}$ bond lengths of the Grt in these eclogites. The results demonstrate that the $\mathrm{Ca}-\mathrm{O}$ bond length difference between Grt and Cpx $\left(\Delta \mathrm{Ca}-\mathrm{O}_{\mathrm{Grt}-\mathrm{Cpx}}\right)$ show a significant increase with increasing $\mathrm{CaO}$ content from 3.4 to $13.6 \mathrm{wt} . \%$ in Grt and with pressure from 2.9 to $6.9 \mathrm{GPa}$. This is consistent with the systematically higher corrected $\mathrm{T}^{44 / 40} \mathrm{Ca}_{\text {Grt-Cpx }}\left(\Delta^{44 / 40} \mathrm{Ca}_{\text {Grt-Cpx }} \times \mathrm{T}^{2} / 10^{6}\right)$ for the Low-TP Roberts Victor eclogites relative to those of High-TP eclogites, and with the negative correlation between $\mathrm{CaO}$ content of garnet and $\Delta^{44 / 40} \mathrm{Ca}_{\text {Grt-Cpx }}$ values. Inter-mineral $\mathrm{Mg}$ isotope fractionation corrected for temperature shows a negative correlation with pressure, indicating a significant pressure effect on inter-mineral $\mathrm{Mg}$ isotope fractionation in addition to temperature. These observations suggest that stable isotope fractionation between Grt and Cpx is controlled by pressure and compositional variations of garnet. Using inter-mineral equilibrium Ca isotope fractionation factors constrained by the Roberts Victor eclogites, we quantitatively model the behaviour of $\mathrm{Ca}$ isotopes during partial melting of eclogite. Results show that stable isotope fractionation by pressure and compositional variations in minerals exerts major controls on isotope fractionation in magmatic systems. Partial melting of eclogite could not significantly fractionate $\mathrm{Ca}$ isotopes and thus is not the cause of low $\delta^{44 / 40} \mathrm{Ca}$ values in previously reported basalts.

\section{Acknowledgments:}

We thank Prof. Yu Ye, Dr. Fei Wu, Sarath Patabendigerada, Dr. Yoann Gréau, and Prof. Dorrit E. Jacob for discussion. We also thank Prof. Qiao Shu for discussion during designing this study. SFF and CFC are funded by ARC grant FL180100134. This research is co-supported by NSFC (41530211), the 111 Project (BP0719022), MOST Special Funds of the State Key Laboratory of Geological Processes and Mineral Resources (MSFGPMR01). We thank Prof. Fangzhen Teng and 
Prof. Jeffrey G. Catalano for editorial handling and three anonymous reviewers for constructive comments, which greatly improved the manuscript. 


\section{References:}

Akhmatskaya, E., Nobes, R., Milman, V. and Winkler, B. (1999) Structural properties of garnets under pressure: An ab initio study. Zeitschrift für Kristallographie-Crystalline Materials 214, 808-819.

Amini, M., Eisenhauer, A., Böhm, F., Holmden, C., Kreissig, K., Hauff, F. and Jochum, K.P. (2009) Calcium Isotopes $(\delta 44 / 40 \mathrm{Ca})$ in MPI-DING Reference Glasses, USGS Rock Powders and Various Rocks: Evidence for Ca Isotope Fractionation in Terrestrial Silicates. Geostandards and Geoanalytical Research 33, 231-247.

Amsellem, E., Moynier, F., Bertrand, H., Bouyon, A., Mata, J., Tappe, S. and Day, J.M.D. (2020) Calcium isotopic evidence for the mantle sources of carbonatites. Science Advances 6.

Amsellem, E., Moynier, F., Pringle, E.A., Bouvier, A., Chen, H. and Day, J.M.D. (2017) Testing the chondrule-rich accretion model for planetary embryos using calcium isotopes. Earth and Planetary Science Letters 469, 75-83.

An, Y., Huang, J.-X., Griffin, W.L., Liu, C. and Huang, F. (2017) Isotopic composition of Mg and Fe in garnet peridotites from the Kaapvaal and Siberian Cratons. Geochimica et Cosmochimica Acta 200, $167-185$.

Antonelli, M.A., Schiller, M., Schauble, E.A., Mittal, T., DePaolo, D.J., Chacko, T., Grew, E.S. and Tripoli, B. (2019) Kinetic and equilibrium Ca isotope effects in high-T rocks and minerals. Earth and Planetary Science Letters 517, 71-82.

Bourdon, B., Roskosz, M. and Hin, R.C. (2018) Isotope tracers of core formation. Earth-Science Reviews 181, 61-81.

Chapman, D.S. and Pollack, H.N. (1977) Regional geotherms and lithospheric thickness. Geology 5, 265-268.

Chen, C., Ciazela, J., Li, W., Dai, W., Wang, Z., Foley, S.F., Li, M., Hu, Z. and Liu, Y. (2020) Calcium isotopic compositions of oceanic crust at various spreading rates. Geochimica et Cosmochimica Acta $278,272-288$

Chen, C.F., Dai, W., Wang, Z.C., Liu, Y.S., Li, M., Becker, H. and Foley, S.F. (2019) Calcium isotope fractionation during magmatic processes in the upper mantle. Geochimica et Cosmochimica Acta 249, 121-137.

Chen, C.F., Liu, Y.S., Feng, L.P., Foley, S.F., Zhou, L., Ducea, M.N. and Hu, Z.C. (2018) Calcium isotope evidence for subduction-enriched lithospheric mantle under the northern North China Craton. Geochimica et Cosmochimica Acta 238, 55-67.

Dai, W., Wang, Z., Liu, Y., Chen, C., Zong, K., Zhou, L., Zhang, G., Li, M., Moynier, F. and Hu, Z. (2020) Calcium isotope compositions of mantle pyroxenites. Geochimica et Cosmochimica Acta 270, 144-159. 
Feng, C.Q., Qin, T., Huang, S.C., Wu, Z.Q. and Huang, F. (2014) First-principles investigations of equilibrium calcium isotope fractionation between clinopyroxene and Ca-doped orthopyroxene. Geochimica et Cosmochimica Acta 143, 132-142.

Feng, L.P., Zhou, L., Yang, L., DePaolo, D.J., Tong, S.-Y., Liu, Y.S., Owens, T.L. and Gao, S. (2017) Calcium Isotopic Compositions of Sixteen USGS Reference Materials. Geostandards and Geoanalytical Research 41, 93-106.

Feng, L.P., Zhou, L., Yang, L., Zhang, W., Wang, Q., Tong, S.Y. and Hu, Z.C. (2018) A rapid and simple single-stage method for $\mathrm{Ca}$ separation from geological and biological samples for isotopic analysis by MC-ICP-MS. Journal of Analytical Atomic Spectrometry 33, 413-421.

Freeman, C.L., Allan, N.L. and van Westrenen, W. (2006) Local cation environments in the pyrope-grossular Mg3A12Si3O12-Ca3A12Si3O12 garnet solid solution. Physical Review B 74, 134203.

Gréau, Y., Huang, J.X., Griffin, W.L., Renac, C., Alard, O. and O’Reilly, S.Y. (2011) Type I eclogites from Roberts Victor kimberlites: Products of extensive mantle metasomatism. Geochimica et Cosmochimica Acta 75, 6927-6954.

Griffin, W.L., O'Reilly, S.Y., Natapov, L.M. and Ryan, C.G. (2003) The evolution of lithospheric mantle beneath the Kalahari Craton and its margins. Lithos 71, 215-241.

Hazen, R.M. and Finger, L.W. (1978) Crystal structures and compressibilities of pyrope and grossular to 60 kbar. American Mineralogist 63, 297-303.

Hazen, R.M. and Finger, L.W. (1989) High-pressure crystal chemistry of andradite and pyrope; revised procedures for high-pressure diffraction experiments. American Mineralogist.

He, Y.S., Wang, Y., Zhu, C.W., Huang, S.C. and Li, S.G. (2017) Mass-Independent and Mass-Dependent Ca Isotopic Compositions of Thirteen Geological Reference Materials Measured by Thermal Ionisation Mass Spectrometry. Geostandards and Geoanalytical Research 41, 283-302.

Heuser, A., Schmitt, A.-D., Gausonne, N. and Wombacher, F. (2016) Analytical methods: Calcium stable isotope geochemistry. Springer Berlin Heidelberg, Berlin, Heidelberg, 23-73.

Hu, Y., Teng, F.-Z., Zhang, H.-F., Xiao, Y. and Su, B.-X. (2016) Metasomatism-induced mantle magnesium isotopic heterogeneity: Evidence from pyroxenites. Geochimica et Cosmochimica Acta 185, 88-111.

Huang, F., Chen, L., Wu, Z. and Wang, W. (2013) First-principles calculations of equilibrium Mg isotope fractionations between garnet, clinopyroxene, orthopyroxene, and olivine: Implications for $\mathrm{Mg}$ isotope thermometry. Earth and Planetary Science Letters 367, 61-70.

Huang, F., Zhou, C., Wang, W., Kang, J. and Wu, Z. (2019) First-principles calculations of equilibrium Ca isotope fractionation: Implications for oldhamite formation and evolution of lunar magma ocean. Earth and Planetary Science Letters 510, 153-160. 
Huang, J.-X., Li, P., Griffin, W.L., Xia, Q.-K., Gréau, Y., Pearson, N.J. and O’Reilly, S.Y. (2014) Water contents of Roberts Victor xenolithic eclogites: primary and metasomatic controls. Contributions to Mineralogy and Petrology 168, 1092.

Huang, J.-X., Xiang, Y., An, Y., Griffin, W.L., Gréau, Y., Xie, L., Pearson, N.J., Yu, H. and O'Reilly, S.Y. (2016) Magnesium and oxygen isotopes in Roberts Victor eclogites. Chemical Geology 438, 73-83.

Huang, J.X., Gréau, Y., Griffin, W.L., O'Reilly, S.Y. and Pearson, N.J. (2012) Multi-stage origin of Roberts Victor eclogites: Progressive metasomatism and its isotopic effects. Lithos 142-143, 161-181.

Huang, S.C., Farkaš, J. and Jacobsen, S.B. (2010) Calcium isotopic fractionation between clinopyroxene and orthopyroxene from mantle peridotites. Earth and Planetary Science Letters 292, 337-344.

Huang, S.C., Farkaš, J. and Jacobsen, S.B. (2011) Stable calcium isotopic compositions of Hawaiian shield lavas: Evidence for recycling of ancient marine carbonates into the mantle. Geochimica et Cosmochimica Acta 75, 4987-4997.

Huang, S.C. and Jacobsen, S.B. (2017) Calcium isotopic compositions of chondrites. Geochimica et Cosmochimica Acta 201, 364-376.

Kang, J.T., Ionov, D.A., Liu, F., Zhang, C.L., Golovin, A.V., Qin, L.P., Zhang, Z.F. and Huang, F. (2017) Calcium isotopic fractionation in mantle peridotites by melting and metasomatism and $\mathrm{Ca}$ isotope composition of the Bulk Silicate Earth. Earth and Planetary Science Letters 474, 128-137.

Kang, J.T., Ionov, D.A., Zhu, H.L., Liu, F., Zhang, Z.F., Liu, Z. and Huang, F. (2019) Calcium isotope sources and fractionation during melt-rock interaction in the lithospheric mantle: Evidence from pyroxenites, wehrlites, and eclogites. Chemical Geology 524, 272-282.

Kang, J.T., Zhu, H.L., Liu, Y.F., Liu, F., Wu, F., Hao, Y.T., Zhi, X.C., Zhang, Z.F. and Huang, F. (2016) Calcium isotopic composition of mantle xenoliths and minerals from Eastern China. Geochimica et Cosmochimica Acta 174, 335-344.

Klemme, S., Blundy, J.D. and Wood, B.J. (2002) Experimental constraints on major and trace element partitioning during partial melting of eclogite. Geochimica et Cosmochimica Acta 66, 3109-3123.

Krogh, E.J. (1988) The garnet-clinopyroxene Fe-Mg geothermometer — a reinterpretation of existing experimental data. Contributions to Mineralogy and Petrology 99, 44-48.

Lesher, C.E. (1990) Decoupling of chemical and isotopic exchange during magma mixing. Nature 344, 235-237.

Levien, L. and Prewitt, C.T. (1981) High-pressure structural study of diopside. American Mineralogist $66,315-323$.

Li, M., Lei, Y., Feng, L., Wang, Z., Belshaw, N.S., Hu, Z., Liu, Y., Zhou, L., Chen, H. and Chai, X. (2018) High-precision Ca isotopic measurement using a large geometry high resolution MC-ICP-MS 
with a dummy bucket. Journal of Analytical Atomic Spectrometry 33, 1707-1719.

Li, W.-Y., Teng, F.-Z., Xiao, Y. and Huang, J. (2011) High-temperature inter-mineral magnesium isotope fractionation in eclogite from the Dabie orogen, China. Earth and Planetary Science Letters 304, 224-230.

Li, Y., Wang, W., Huang, S., Wang, K. and Wu, Z. (2019) First-principles investigation of the concentration effect on equilibrium fractionation of $\mathrm{K}$ isotopes in feldspars. Geochimica et Cosmochimica Acta 245, 374-384.

Liu, F., Li, X., Wang, G.Q., Liu, Y.F., Zhu, H.L., Kang, J.T., Huang, F., Sun, W.D., Xia, X.P. and Zhang, Z.F. (2017a) Marine Carbonate Component in the Mantle Beneath the Southeastern Tibetan Plateau: Evidence From Magnesium and Calcium Isotopes. Journal of Geophysical Research: Solid Earth 122, 9729-9744.

Liu, F., Zhu, H.L., Li, X., Wang, G.Q. and Zhang, Z.F. (2017b) Calcium Isotopic Fractionation and Compositions of Geochemical Reference Materials. Geostandards and Geoanalytical Research 41, 675-688.

Liu, S.A., Teng, F.Z., Yang, W. and Wu, F.Y. (2011) High-temperature inter-mineral magnesium isotope fractionation in mantle xenoliths from the North China craton. Earth and Planetary Science Letters 308, 131-140.

Macgregor, I.D. and Carter, J.L. (1970) The chemistry of clinopyroxenes and garnets of eclogite and peridotite xenoliths from the Roberts Victor mine, South Africa. Physics of the Earth and Planetary Interiors 3, 391-397.

McCandless, T. and Gurney, J. (1989) Sodium in garnet and potassium in clinopyroxene: criteria for classifying mantle eclogites. Kimberlites and related rocks 2, 827-832.

Nestola, F., Boffa Ballaran, T., Liebske, C., Thompson, R. and Downs, R.T. (2008) The effect of the hedenbergitic substitution on the compressibility of jadeite. American Mineralogist 93, 1005-1013.

Novak, G.A. and Gibbs, G.V. (1971) The Crystal Chemistry of the Silicate Garnets. American Mineralogist 56, 791-825.

Schauble, E.A. (2004) Applying Stable Isotope Fractionation Theory to New Systems. Reviews in Mineralogy and Geochemistry 55, 65-111.

Schauble, E.A. (2011) First-principles estimates of equilibrium magnesium isotope fractionation in silicate, oxide, carbonate and hexaaquamagnesium(2+) crystals. Geochimica et Cosmochimica Acta 75, 844-869.

Schiller, M., Paton, C. and Bizzarro, M. (2012) Calcium isotope measurement by combined HR-MC-ICPMS and TIMS. Journal of Analytical Atomic Spectrometry 27, 38-49.

Schulze, D.J., Valley, J.W. and Spicuzza, M.J. (2000) Coesite eclogites from the Roberts Victor 
kimberlite, South Africa. Lithos 54, 23-32.

Shannon, R.D. (1976) Revised effective ionic radii and systematic studies of interatomic distances in halides and chalcogenides. Acta crystallographica section A: crystal physics, diffraction, theoretical and general crystallography 32, 751-767.

Smith, C.B., Allsop, H.L., Kramers, J.D., Hutchinson, G. and Roddick, J.C. (1985) Emplacement ages of Jurassic-Cretaceous South African kimberlites by the Rb-Sr method on phlogopite and whole-rock samples. Transactions of the Geological Society of South Africa 88, 249-266.

Stracke, A., Tipper, E.T., Klemme, S. and Bizimis, M. (2018) Mg isotope systematics during magmatic processes: Inter-mineral fractionation in mafic to ultramafic Hawaiian xenoliths. Geochimica et Cosmochimica Acta 226, 192-205.

Sun, C. and Liang, Y. (2015) A REE-in-garnet-clinopyroxene thermobarometer for eclogites, granulites and garnet peridotites. Chemical Geology 393-394, 79-92.

Teng, F.Z., Dauphas, N., Helz, R.T., Gao, S. and Huang, S. (2011) Diffusion-driven magnesium and iron isotope fractionation in Hawaiian olivine. Earth and Planetary Science Letters 308, 317-324.

Urey, H.C. (1947) The thermodynamic properties of isotopic substances. Journal of the Chemical Society (Resumed), 562-581.

Valdes, M.C., Moreira, M., Foriel, J. and Moynier, F. (2014) The nature of Earth's building blocks as revealed by calcium isotopes. Earth and Planetary Science Letters 394, 135-145.

van der Laan, S., Zhang, Y., Kennedy, A.K. and Wyllie, P.J. (1994) Comparison of element and isotope diffusion of $\mathrm{K}$ and $\mathrm{Ca}$ in multicomponent silicate melts. Earth and Planetary Science Letters 123, $155-166$.

Walker, A.M., Tyer, R.P., Bruin, R.P. and Dove, M.T. (2008) The compressibility and high pressure structure of diopside from first principles simulation. Physics and Chemistry of Minerals 35, 359-366.

Wang, F.F. (1973) Physical and Chemical properties of Garnets, Treatise on Materials Science \& Technology. Elsevier, pp. 279-384.

Wang, S.-J., Teng, F.-Z., Rudnick, R.L. and Li, S.-G. (2015) Magnesium isotope evidence for a recycled origin of cratonic eclogites. Geology 43, 1071-1074.

Wang, S.-J., Teng, F.-Z., Williams, H.M. and Li, S.-G. (2012) Magnesium isotopic variations in cratonic eclogites: Origins and implications. Earth and Planetary Science Letters 359-360, 219-226.

Wang, W., Qin, T., Zhou, C., Huang, S., Wu, Z. and Huang, F. (2017a) Concentration effect on equilibrium fractionation of $\mathrm{Mg}$-Ca isotopes in carbonate minerals: Insights from first-principles calculations. Geochimica et Cosmochimica Acta 208, 185-197.

Wang, W., Zhou, C., Qin, T., Kang, J.-T., Huang, S., Wu, Z. and Huang, F. (2017b) Effect of Ca content on equilibrium $\mathrm{Ca}$ isotope fractionation between orthopyroxene and clinopyroxene. Geochimica et 
Cosmochimica Acta 219, 44-56.

Wang, Y., He, Y., Wu, H., Zhu, C., Huang, S. and Huang, J. (2019) Calcium isotope fractionation during crustal melting and magma differentiation: Granitoid and mineral-pair perspectives. Geochimica et Cosmochimica Acta 259, 37-52.

Williams, H.M. and Bizimis, M. (2014) Iron isotope tracing of mantle heterogeneity within the source regions of oceanic basalts. Earth \& Planetary Science Letters 404, 396-407.

Yang, H. and Ghose, S. (1995) High temperature single crystal X-ray diffraction studies of the ortho-proto phase transition in enstatite, Mg2Si2O6 at $1360 \mathrm{~K}$. Physics and Chemistry of Minerals 22, 300-310.

Young, E.D., Manning, C.E., Schauble, E.A., Shahar, A., Macris, C.A., Lazar, C. and Jordan, M. (2015) High-temperature equilibrium isotope fractionation of non-traditional stable isotopes: Experiments, theory, and applications. Chemical Geology 395, 176-195.

Zhang, H., Wang, Y., He, Y., Teng, F.-Z., Jacobsen, S.B., Helz, R.T., Marsh, B.D. and Huang, S. (2018) No Measurable Calcium Isotopic Fractionation During Crystallization of Kilauea Iki Lava Lake. Geochemistry, Geophysics, Geosystems 19,3128-3139.

Zhao, X.M., Zhang, Z.F., Huang, S.C., Liu, Y.F., Li, X. and Zhang, H.F. (2017) Coupled Extremely Light $\mathrm{Ca}$ and Fe Isotopes in Peridotites. Geochimica et Cosmochimica Acta 208, 368-380. 


\section{Figure captions}

Figure 1. (a) Average Ca-O (black solid line) and $\mathrm{Mg}-\mathrm{O}$ bond lengths (grey dotted line) in the pyrope-grossular garnet solid solutions with the variation of $\mathrm{Ca}$ content at 1 atm from ab initio calculations (x represents atoms per formula unit $\left.\left(\mathrm{Ca}_{\mathrm{x}}, \mathrm{Mg}_{\mathrm{y}}, \mathrm{Fe}_{3-\mathrm{x}-\mathrm{y}}\right) \mathrm{Al}_{2} \mathrm{Si}_{3} \mathrm{O}_{12}\right)$ (Freeman et al., 2006). Garnets in Roberts Victor eclogites are plotted on the lines for calculation of $\mathrm{Ca}-\mathrm{O}$ and $\mathrm{Mg}-\mathrm{O}$ bond lengths. $\mathrm{Ca}-\mathrm{O}$ bond lengths of $\mathrm{Cpx}$ in the Roberts Victor eclogites are shown for comparison (grey band: 0.450 to $0.460 \AA$ ). (b) Variation of $\mathrm{Ca}-\mathrm{O}$ bond lengths in garnet and clinopyroxene with increasing pressure from theoretical calculations and experiments. Green, red, and purple lines represent Cpx with variable Jd contents (Nestola et al., 2008). The Ca-O bond lengths of diopside (Di) obtained by first principles and experiments are from Walker et al. (2008) and Levien and Prewitt (1981), respectively. Ca-O bond lengths of grossular obtained by ab initio calculation and experiment are from Akhmatskaya et al. (1999) and Hazen and Finger (1978), respectively. The $\mathrm{Ca}-\mathrm{O}$ bond length of the andradite obtained by the experiment is from Hazen and Finger (1989). The numbers on the lines represent the rate of decrease of bond length as increasing pressure. The decrease of the bond length in Cpx is more significant than in grossular.

Figure 2. Calcium isotope compositions of the garnets and clinopyroxenes in the Roberts Victor $(\mathrm{RV})$ eclogite xenoliths. Filled symbols $=$ garnets $(\mathrm{Grt})$ and open symbols $=$ clinopyroxenes $(\mathrm{Cpx})$. The eclogite xenoliths from the central Siberian craton (Kang et al., 2019) and orogenic eclogites and peridotites from the Dabie orogen (Wang et al., 2019) are shown for comparison. The estimated $\delta{ }^{4 / 40} \mathrm{Ca}$ of the mantle (light green band) is from Chen et al. (2019) and Kang et al. (2017).

Figure 3. (a) Inter-mineral $\mathrm{Ca}$ isotope fractionation and $\mathrm{Mg}$ isotope fractionation (Huang et al., 2016) in the Roberts Victor eclogites. The uncertainties of $\Delta^{44 / 40} \mathrm{Ca}_{\mathrm{Grt}-\mathrm{Cpx}}$ and $\Delta^{26} \mathrm{Mg}_{\mathrm{Grt}-\mathrm{Cpx}}$ are calculated by propagating the analytical errors on both garnet (Grt) and clinopyroxene (Cpx). (b) $\delta^{26} \mathrm{Mg}_{\mathrm{Grt}}$ versus $\delta^{26} \mathrm{Mg}_{\mathrm{Cpx}}$ for the Roberts Victor eclogites in this study, previous reported Kaapvaal eclogites and garnet peridotites (An et al., 2017; Wang et al., 2015; Wang et al., 2012), orogenic eclogites from the Dabie orogen (Li et al., 2011), and garnet pyroxenite xenoliths from Hawaiian 
(Stracke et al., 2018) and Hannuoba (Hu et al., 2016). Equilibrium Mg isotope fractionations for different temperatures are calculated from Huang et al. (2013) at 3 (grey solid line) and 7 GPa (grey dotted line). The grey arrow implies the trend of inter-mineral $\mathrm{Mg}$ isotope disequilibrium, as indicated by Wang et al. (2015) and Hu et al. (2016).

Figure 4. (a) Plots of $\mathrm{CaO}$ content versus inter-mineral $\mathrm{Ca}$ isotope fractionation between coexisting garnet and clinopyroxene in eclogites from Roberts Victor (this study) and the central Siberian craton (Kang et al., 2019). Orogenic eclogites and peridotites from the Dabie orogen (Wang et al., 2019) are shown for comparison. (b) Plots of $\mathrm{CaO}$ content versus inter-mineral $\mathrm{Ca}$ isotope fractionation corrected for temperature effect. The uncertainty of $\mathrm{T}^{2} / 10^{6 *} \Delta^{44 / 40} \mathrm{Ca}_{\mathrm{Grt}-\mathrm{Cpx}}$ is calculated by propagating the errors on temperature $(50 \mathrm{~K})$ and $\Delta^{44 / 40} \mathrm{Ca}_{\mathrm{Grt}-\mathrm{Cpx}}$.

Figure 5. (a) $\mathrm{CaO}$ content in Grt versus $\mathrm{Ca}-\mathrm{O}$ bond length difference between $\mathrm{Grt}$ and $\mathrm{Cpx}$ $\left(\Delta \mathrm{Ca}-\mathrm{O}_{\mathrm{Grt}-\mathrm{Cpx}}\right)$ at their equilibration pressures and $1 \mathrm{~atm}$ in the Roberts Victor eclogites. (b) $\Delta \mathrm{Ca}-\mathrm{O}_{\mathrm{Grt}-\mathrm{Cpx}}$ at their equilibration pressures versus inter-mineral $\mathrm{Ca}$ isotope fractionation corrected for temperature effect $\left(\Delta^{44 / 40} \mathrm{Ca}_{\mathrm{Grt}-\mathrm{Cpx}} \times \mathrm{T}^{2} / 10^{6}\right)$. The uncertainty calculation is as Fig. $4 \mathrm{~b}$.

Figure 6. Plots of $\mathrm{SiO}_{2}$ (a) and $\mathrm{Cr}_{2} \mathrm{O}_{3}$ (b) contents in the garnets versus those in the clinopyroxenes from the Roberts Victor eclogites. Positive correlations of major elements $\mathrm{SiO}_{2}$ and $\mathrm{Cr}_{2} \mathrm{O}_{3}$ indicates that chemical equilibrium has achieved.

Figure 7. Equilibrium $\mathrm{Ca}$ isotope fractionation between garnet and clinopyroxene in the Roberts Victor eclogites. Blue lines represent equilibrium $\mathrm{Ca}$ isotope fractionation at about $3 \mathrm{GPa}$ and $\mathrm{CaO}$ content of garnet of 5 and 12.7 wt.\%, respectively. Red lines represent equilibrium $\mathrm{Ca}$ isotope fractionation at 4.4-6.9 GPa and $\mathrm{CaO}$ content of garnet of 5 and $13.6 \mathrm{wt} . \%$, respectively. The blue and red equilibrium fractionation lines were obtained from the $\Delta^{44 / 40} \mathrm{Ca}_{\mathrm{Grt}-\mathrm{Cpx}}$ values in the Low-TP and High-TP eclogites, respectively. First-principles calculations about $\mathrm{Ca}$ isotope fractionation between grossular (Grs), pyrope (Pyr) with $\mathrm{Ca} / \mathrm{Mg}$ of $1 / 23$ and diopside (Di) at $1 \mathrm{~atm}$ are shown for comparison (Antonelli et al., 2019; Huang et al., 2019). The blue dotted arrow indicates the effect of increasing $\mathrm{CaO}$ content in garnet on equilibrium $\mathrm{Ca}$ isotope fractionation. The black 
dotted arrow indicates the effect of increasing pressure on equilibrium $\mathrm{Ca}$ isotope fractionation. The red dotted arrows indicate the effect of increasing pressure and $\mathrm{CaO}$ content of garnet. The uncertainty of $\mathrm{T}^{2} / 10^{6}$ is calculated by propagating the error on temperature $(50 \mathrm{~K})$.

Figure 8. (a) Inter-mineral $\mathrm{Ca}$ isotope fractionation corrected for temperature $\left(\Delta^{44 / 40} \mathrm{Ca}_{\mathrm{Grt}-\mathrm{Cpx}} \times\right.$ $\left.\mathrm{T}^{2} / 10^{6}\right)$ versus inter-mineral $\mathrm{Mg}$ isotope fractionation corrected for temperature $\left(\Delta^{26} \mathrm{Mg}_{\mathrm{Grt}-\mathrm{Cpx}} \times\right.$ $\mathrm{T}^{2} / 10^{6}$ ) in the Roberts Victor eclogites. (b) $\Delta^{26} \mathrm{Mg}_{\text {Grt-Cpx }} \times \mathrm{T}^{2} / 10^{6}$ versus the equilibrium pressure in the Roberts Victor eclogites and previously reported Kaapvaal eclogites (Wang et al., 2015; Wang et al., 2012). The equilibrium temperature and pressure of the previously reported Kaapvaal eclogites are estimated using the method in this study as described in Section 2. Other published $\mathrm{Mg}$ isotopes of eclogites and garnet pyroxenites are omitted due to the poorly constraints on the equilibrium pressures. The uncertainty calculation is as Fig. 4.

Figure 9. Modelled $\delta^{44 / 40} \mathrm{Ca}$ of basaltic melt and residual eclogite with an increasing degree of melting of eclogite. Green lines are the modelled results using the isotope fractionation factor from Kang et al. (2019). Red lines are the modelled results using isotope fractionation factor from $\Delta^{44 / 40} \mathrm{Ca}_{\mathrm{Grt}-\mathrm{Cpx}}$ of the High-TP eclogites as a function of $\mathrm{CaO}$ content of their garnets in this study $\left(\Delta^{44 / 40} \mathrm{Ca}_{\mathrm{Grt}-\mathrm{Cpx}}=-0.65^{*} \mathrm{CaO}+0.67\right)$. The light red and red bands represent the uncertainties of the modelled results. The uncertainties are calculated by propagating the uncertainty of the slope and intercept for $\Delta^{44 / 40} \mathrm{Ca}_{\mathrm{Grt}-\mathrm{Cpx}}=-0.65^{*} \mathrm{CaO}+0.67$ (0.011 and 0.077 , respectively). For details of all modelling calculations see Table S2. The $\delta^{44 / 40} \mathrm{Ca}$ values of oceanic island basalts (OIBs, grey area) (Valdes et al., 2014) are shown for comparison. The $\delta^{44 / 40} \mathrm{Ca}$ in the starting eclogite is assumed to be $0.90 \%$, the average value of the Type I Roberts Victor eclogites (Table 1). 
Table 1. Chemical compositions, bond lengths and $\mathrm{Ca}$ and $\mathrm{Mg}$ isotope compositions of the Roberts Victor eclogites.

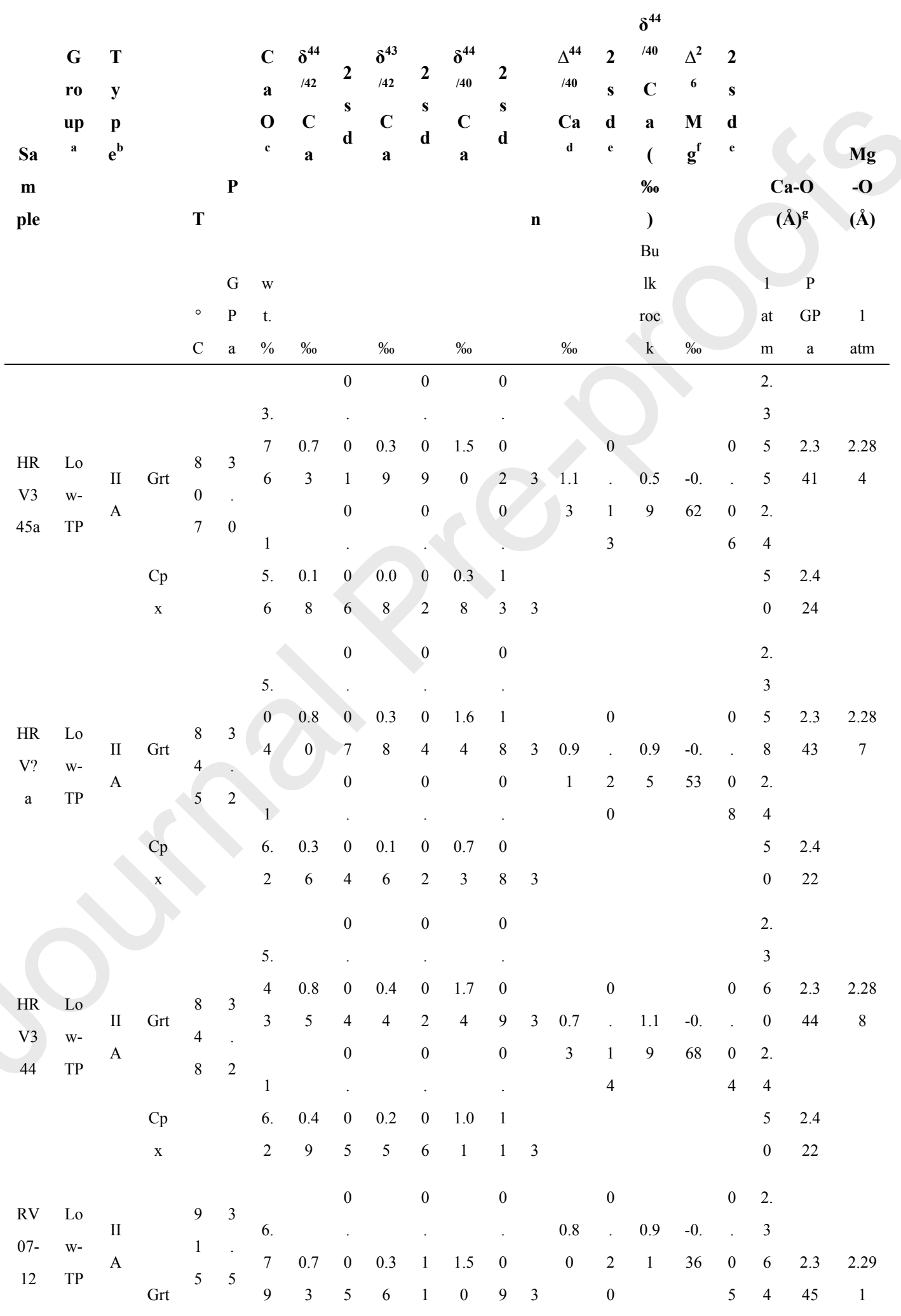




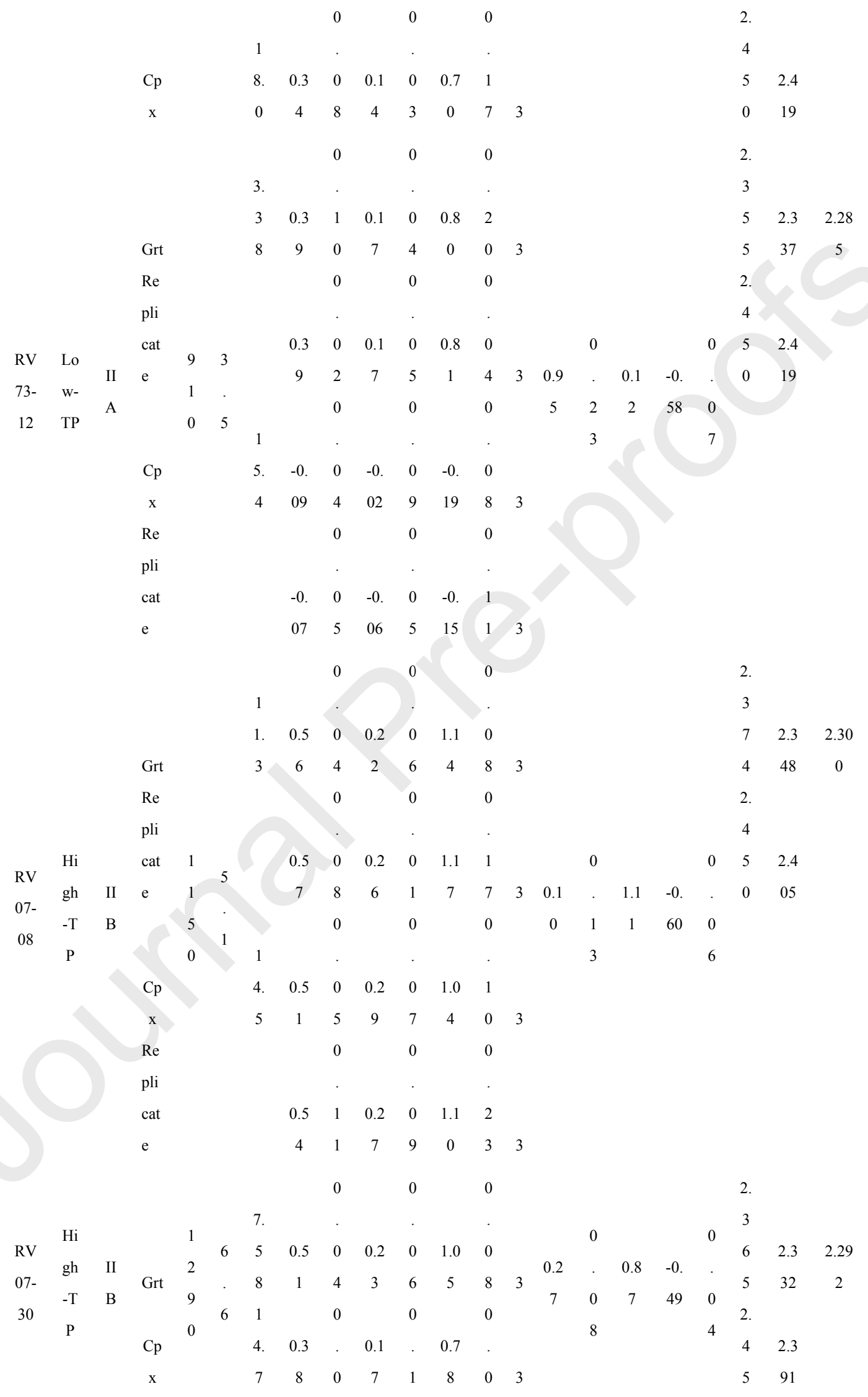




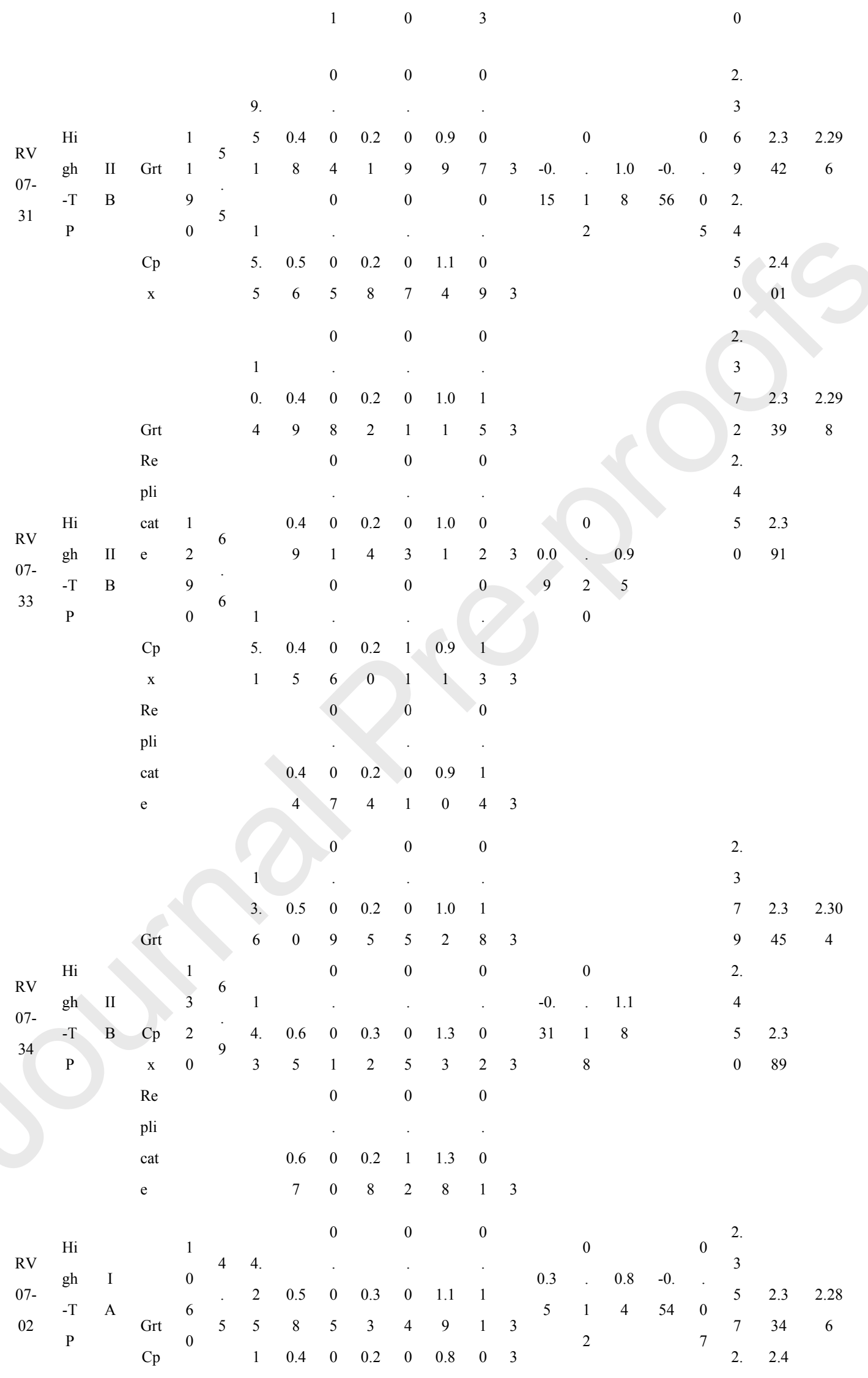




$$
\begin{aligned}
& \begin{array}{llllllllllll}
\mathrm{x} & 4 . & 1 & . & 0 & . & 3 & . & 4 & 10
\end{array} \\
& \begin{array}{lllll}
4 & 0 & 0 & 5
\end{array} \\
& 2 \quad 3 \quad 5 \quad 0 \\
& 0 \quad 0 \quad 0 \quad 2 . \\
& \text { 5. . . . . } 3 \\
& \begin{array}{ccccccccccccccccccccccc} 
& \text { Hi } & & & 1 & & 2 & 0.5 & 0 & 0.2 & 0 & 1.0 & 1 & & & 0 & & & 0 & 6 & 2.3 & 2.28 \\
07- & \text { gh } & \text { I } & \text { Grt } & 2 & 5 & 0 & 3 & 7 & 8 & 9 & 9 & 4 & 3 & 0.1 & . & 0.9 & -0 . & . & 1 & 31 & 9 \\
& -\mathrm{T} & \text { A } & & 0 & . & & & 0 & & 0 & & 0 & & 8 & 2 & 6 & 45 & 1 & 2 . & &
\end{array}
\end{aligned}
$$

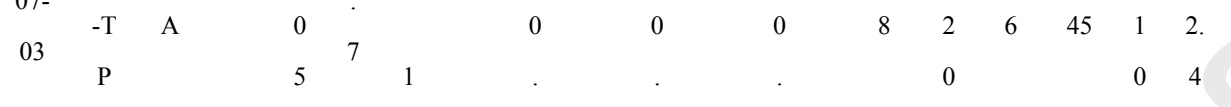

$$
\begin{aligned}
& \begin{array}{llllllllllllll}
\mathrm{Cp} & 4 . & 0.4 & 0 & 0.1 & 0 & 0.9 & 1 & 5 & 2.3
\end{array} \\
& \begin{array}{lllllllllllll}
\mathrm{x} & 8 & 5 & 7 & 9 & 5 & 1 & 4 & 3 & 0 & 99
\end{array} \\
& \begin{array}{llll}
0 & 0 & 0 & 2 .
\end{array}
\end{aligned}
$$

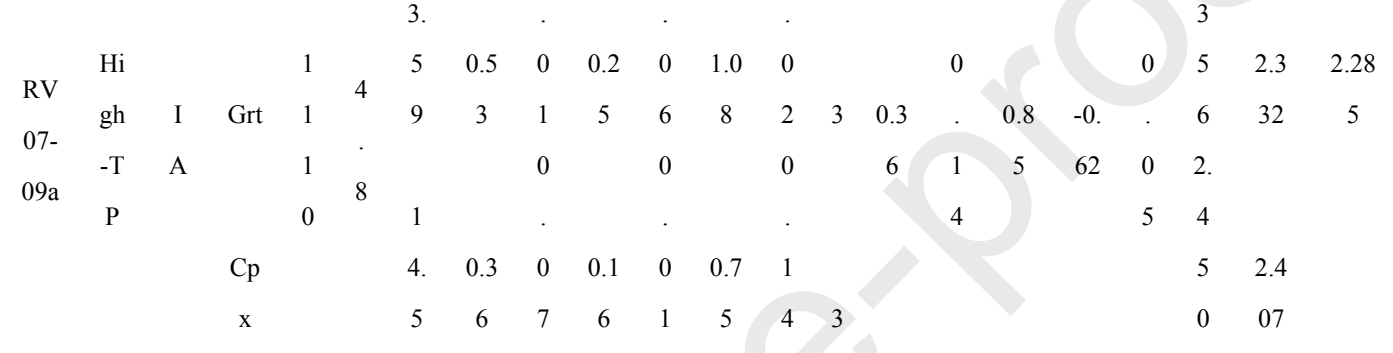

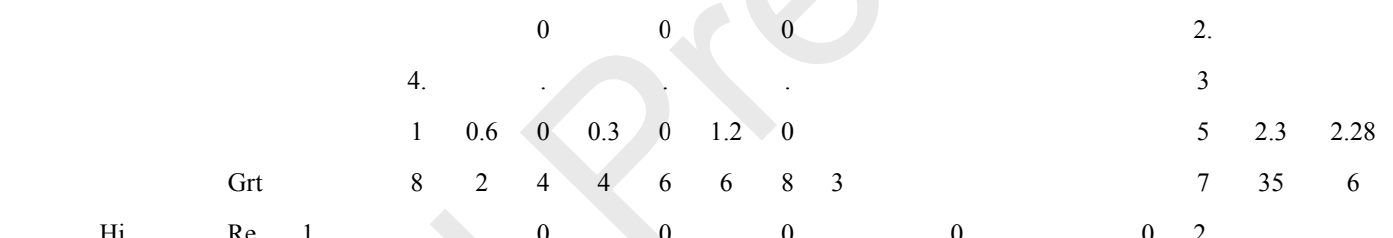

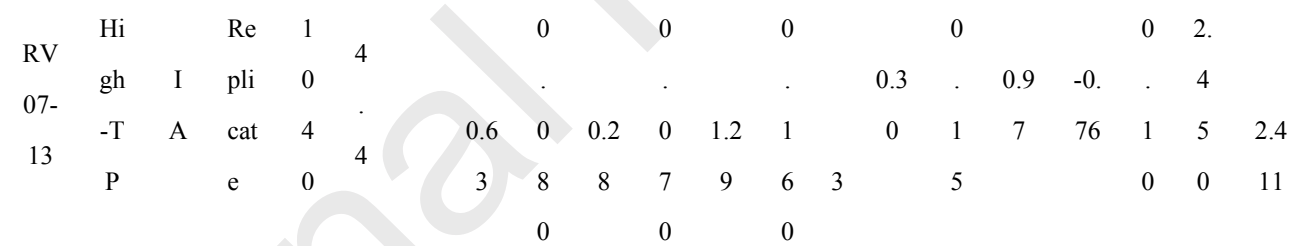

$$
\begin{aligned}
& \begin{array}{lllllllll} 
& 1 & & & & & & & \\
\mathrm{Cp} & 3 . & 0.4 & 0 & 0.1 & 1 & 0.9 & 1
\end{array} \\
& \begin{array}{lllllllll}
\mathrm{x} & 4 & 8 & 6 & 7 & 1 & 7 & 2 & 3
\end{array}
\end{aligned}
$$

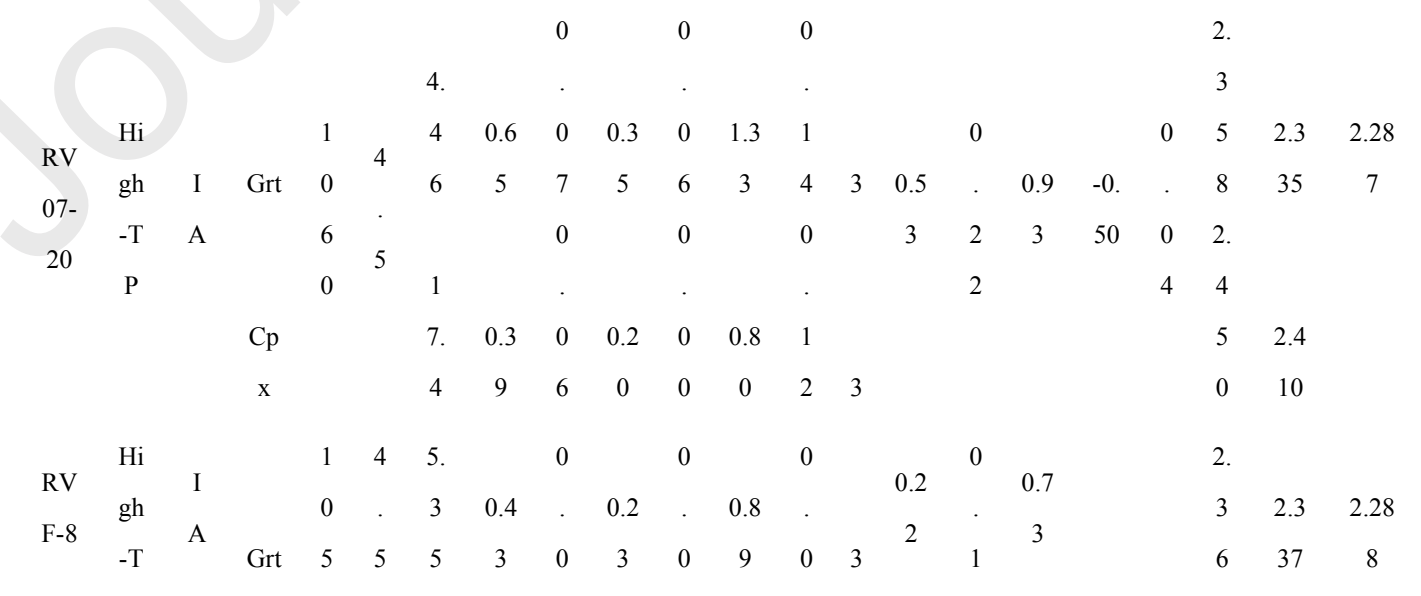




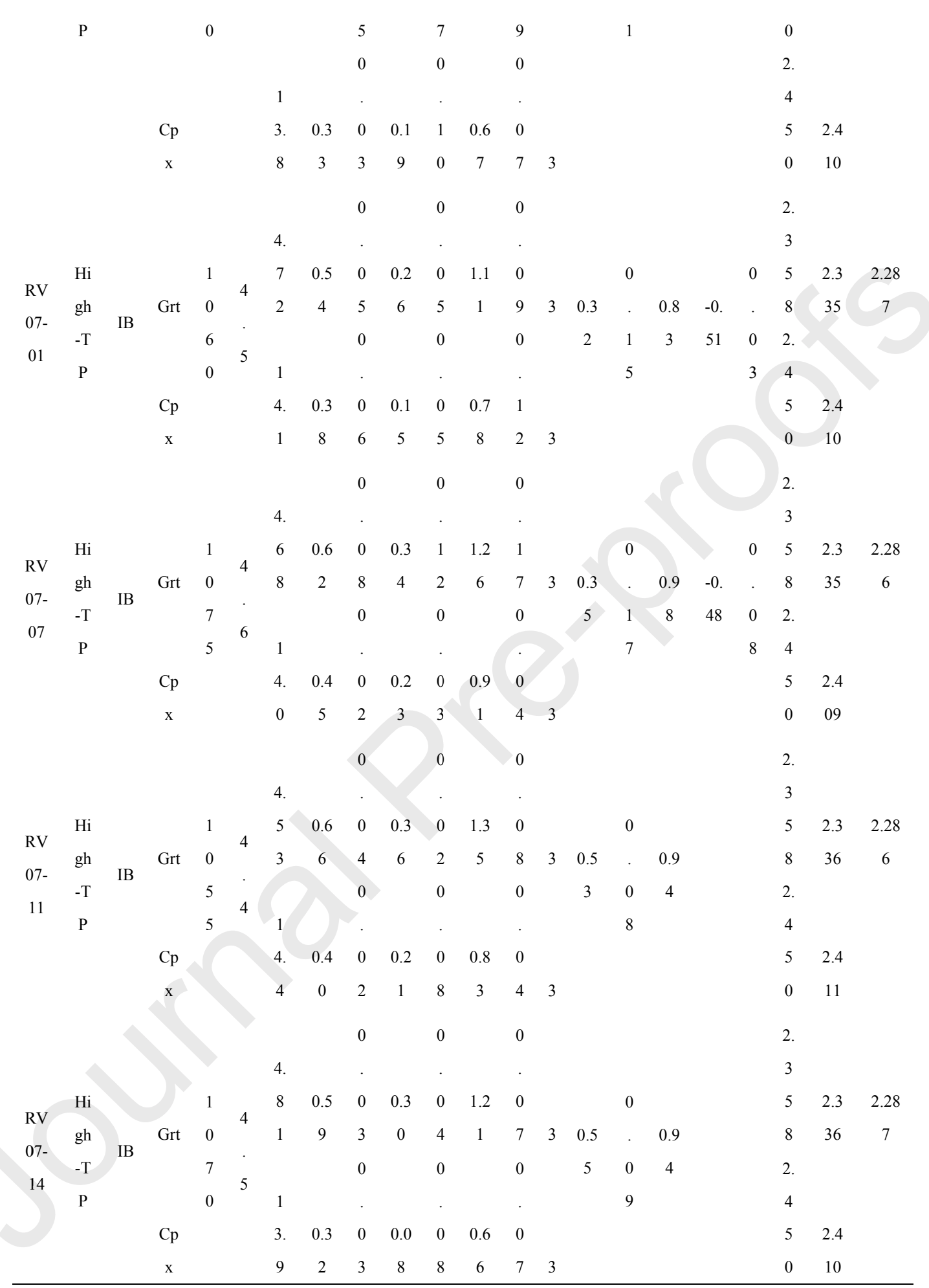

a: According to the equilibrium temperature and pressure, these eclogites are divided into low-temperature and pressure eclogites (Low-TP, 810-910 ${ }^{\circ} \mathrm{C}$ and 2.9-3.5 GPa) and high- temperature and pressure eclogites (High-TP, > $1050{ }^{\circ} \mathrm{C}$ and 4.4-6.9 GPa). b: The classification is from Huang et al. 2016. c: CaO content is from Gréau et al. 2011. $\mathrm{d}:$ Whole rock $\delta^{44 / 40} \mathrm{Ca}(\%)$ is calculated based on mineral separate data in this study and mineral modal abundance from Huang et al. 2016. e:The analytical uncertainty of $\Delta^{44 / 40} \mathrm{Ca}$ and $\Delta^{26} \mathrm{Mg}$ is calculated by propagating the analytical errors on both garnet and clinopyroxene. 
f: Bulk rock $\Delta^{26} \mathrm{Mg}$ values are from Huang et al. 2016. g: For the calculation method for bond lengths of the garnets and clinopyroxenes at $0 \mathrm{GPa}$ and their equilibrated pressures (P GPa), see the main text.

Note: Grt-garnet, Cpx-clinopyroxene, Replicate-replicate digestion of the same sample powder. 


\section{Declaration of interests}

$\bigotimes$ The authors declare that they have no known competing financial interests or personal relationships that could have appeared to influence the work reported in this paper. 


\section{Figure 1}
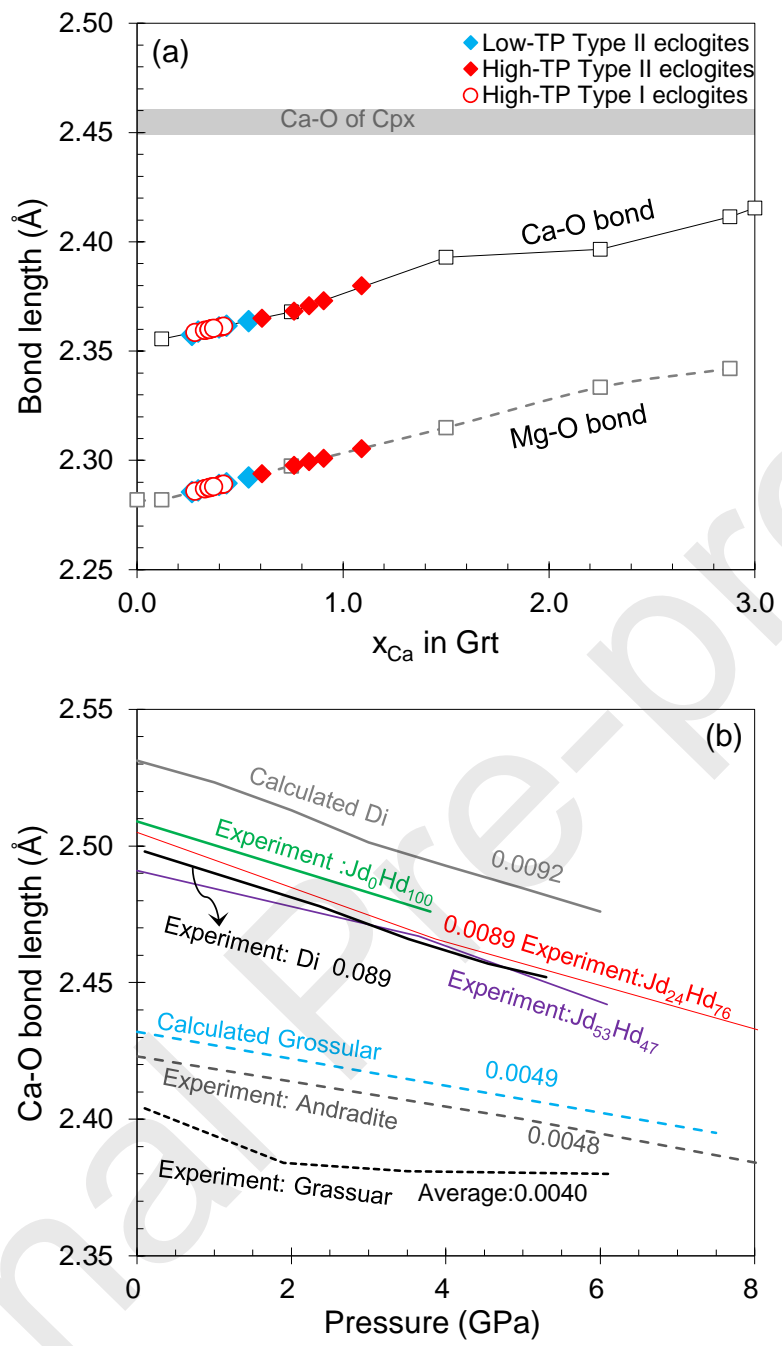
Figure 2

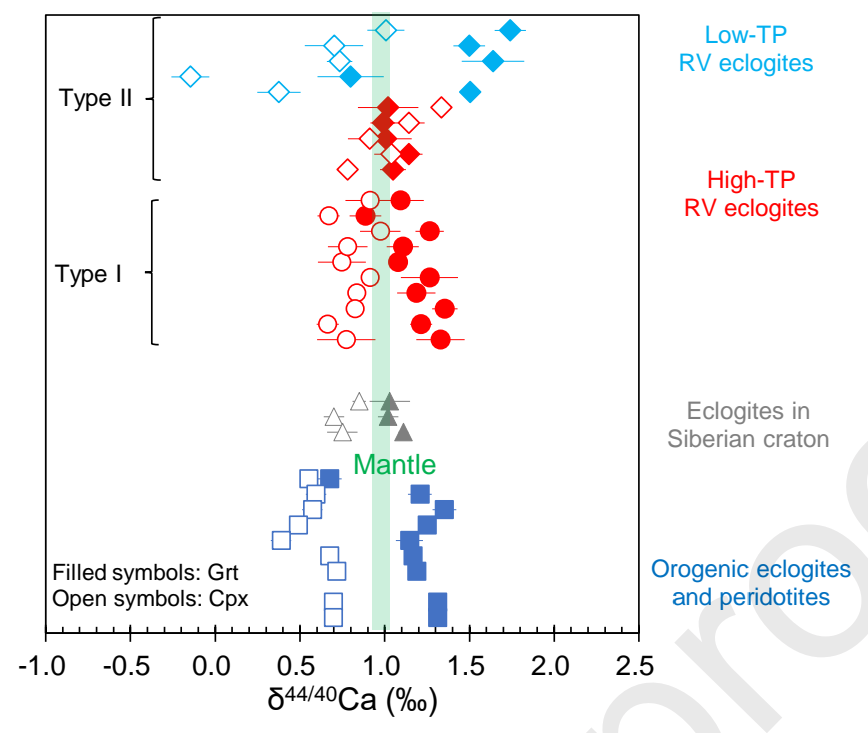


Figure 3
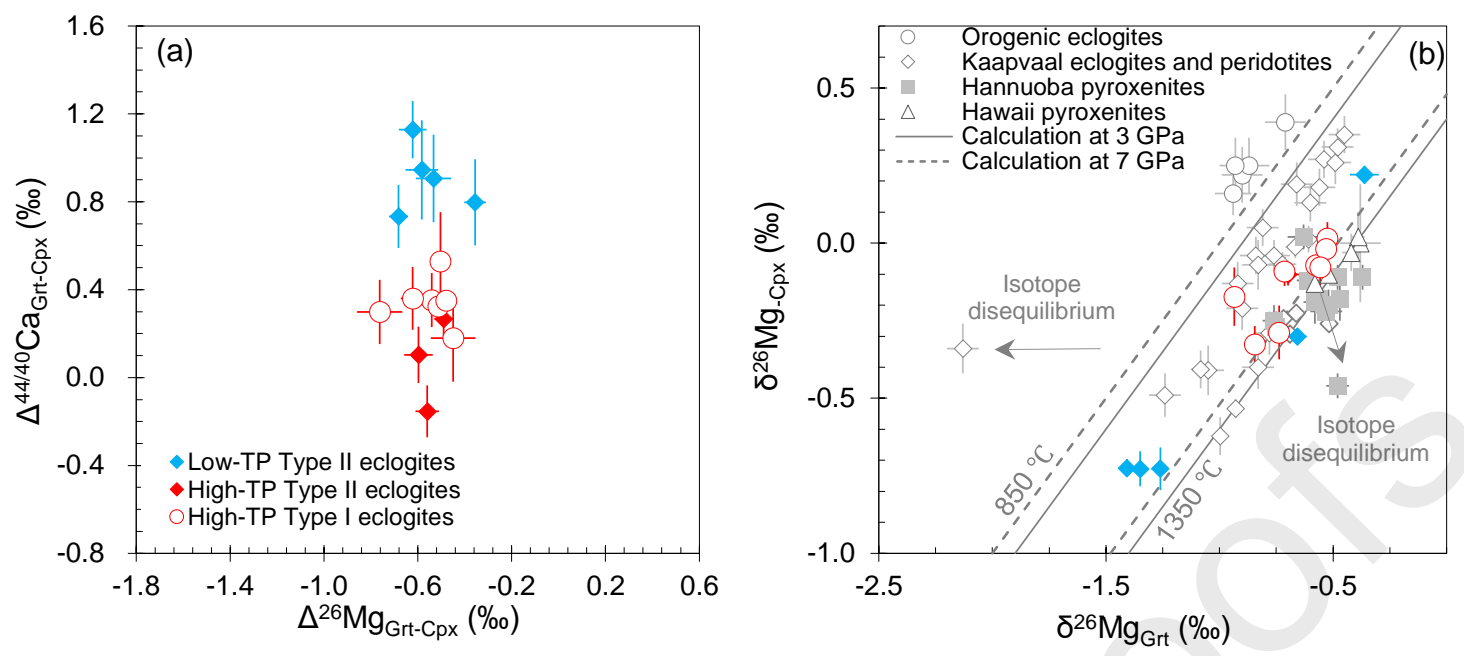
Figure 4
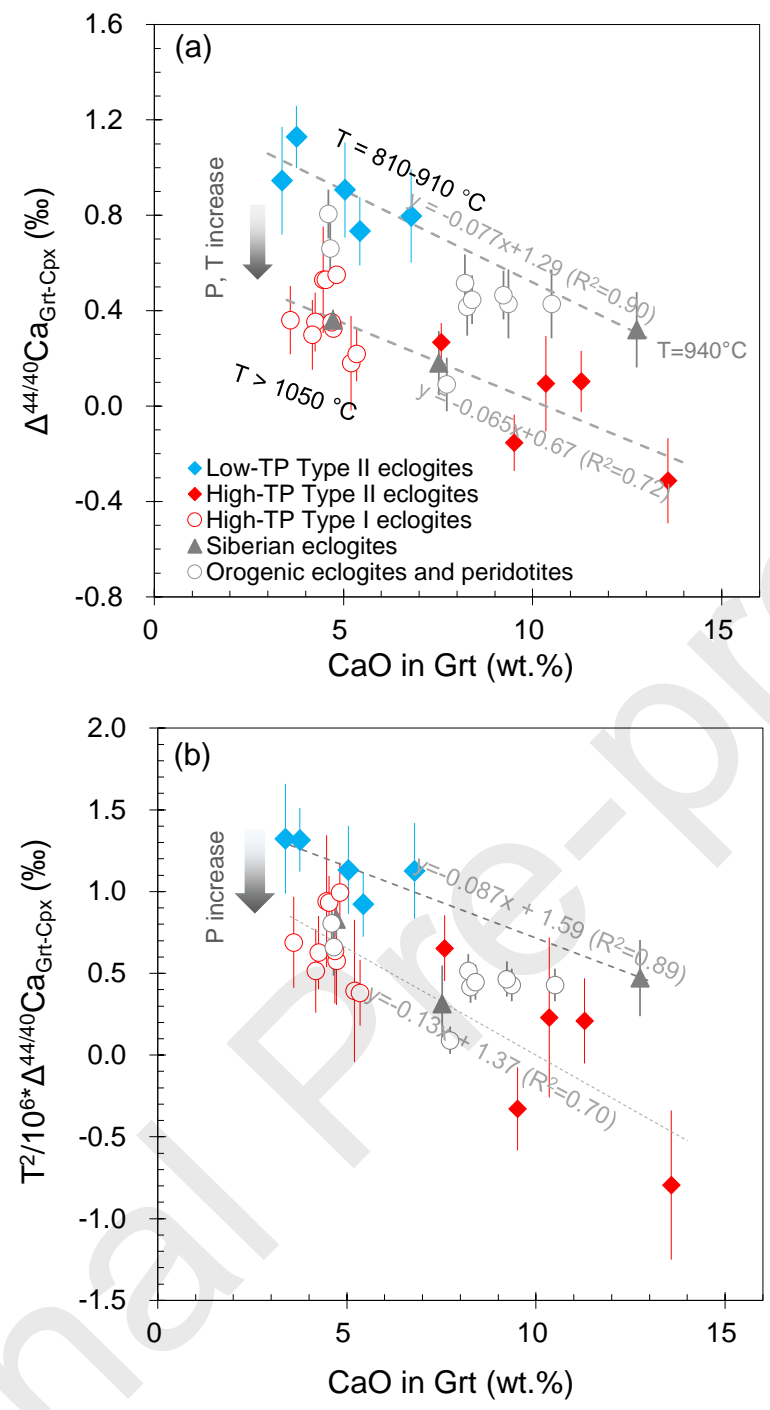


\section{Figure 5}
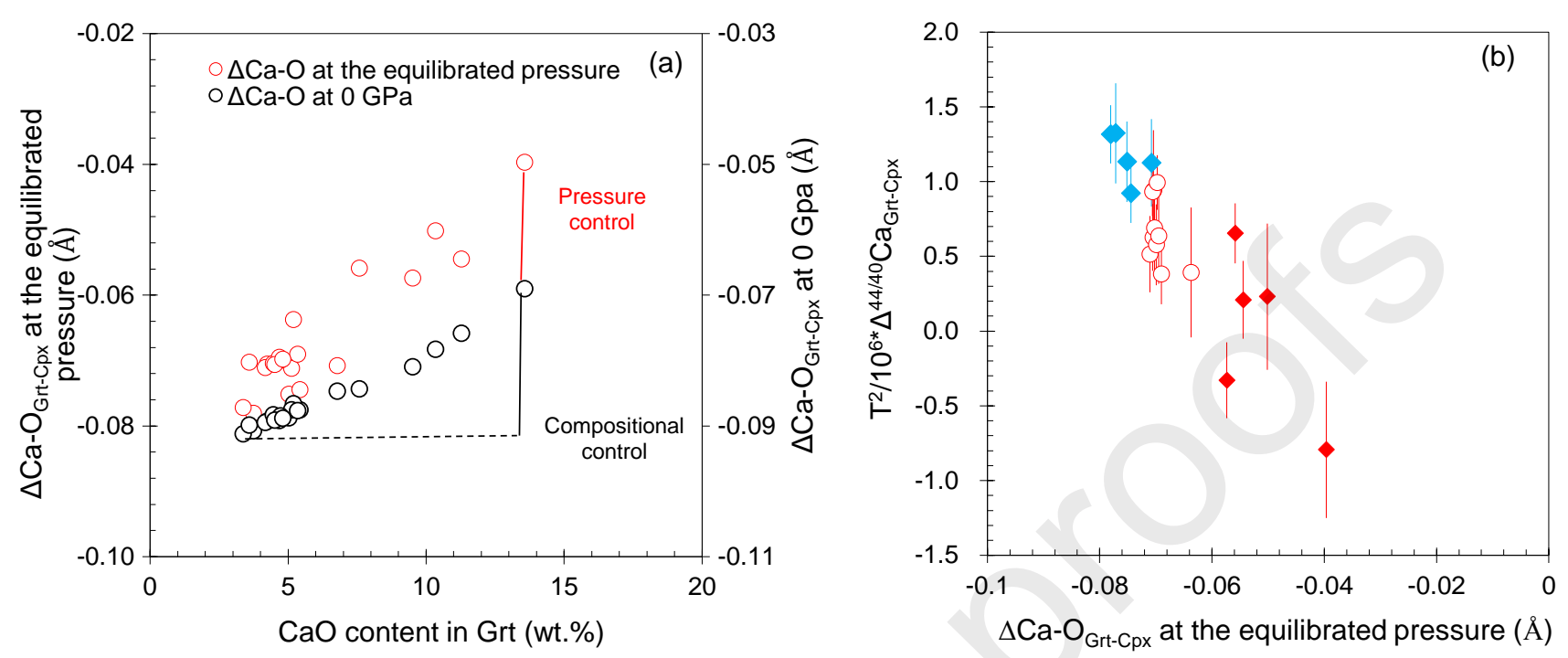


\section{Figure 6}
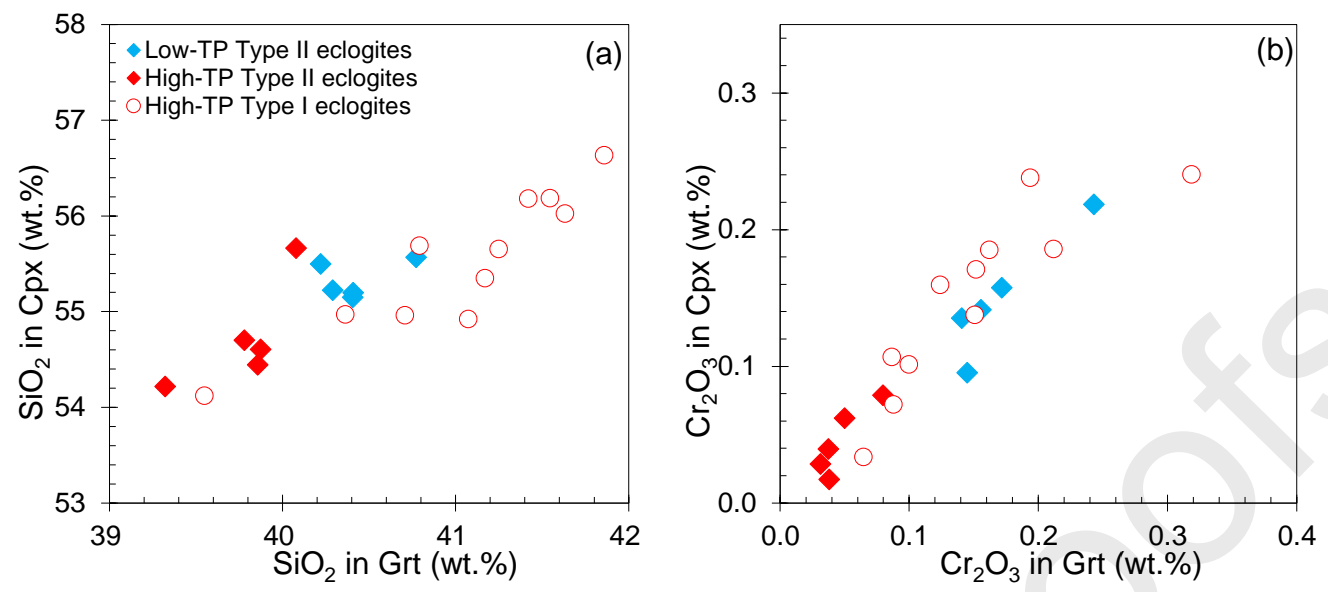


\section{Figure 7}

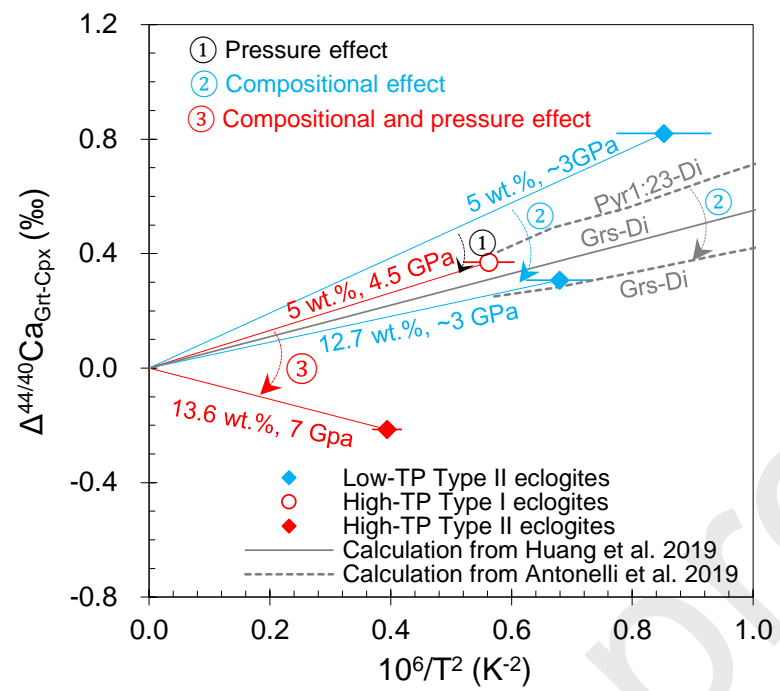


Figure 8
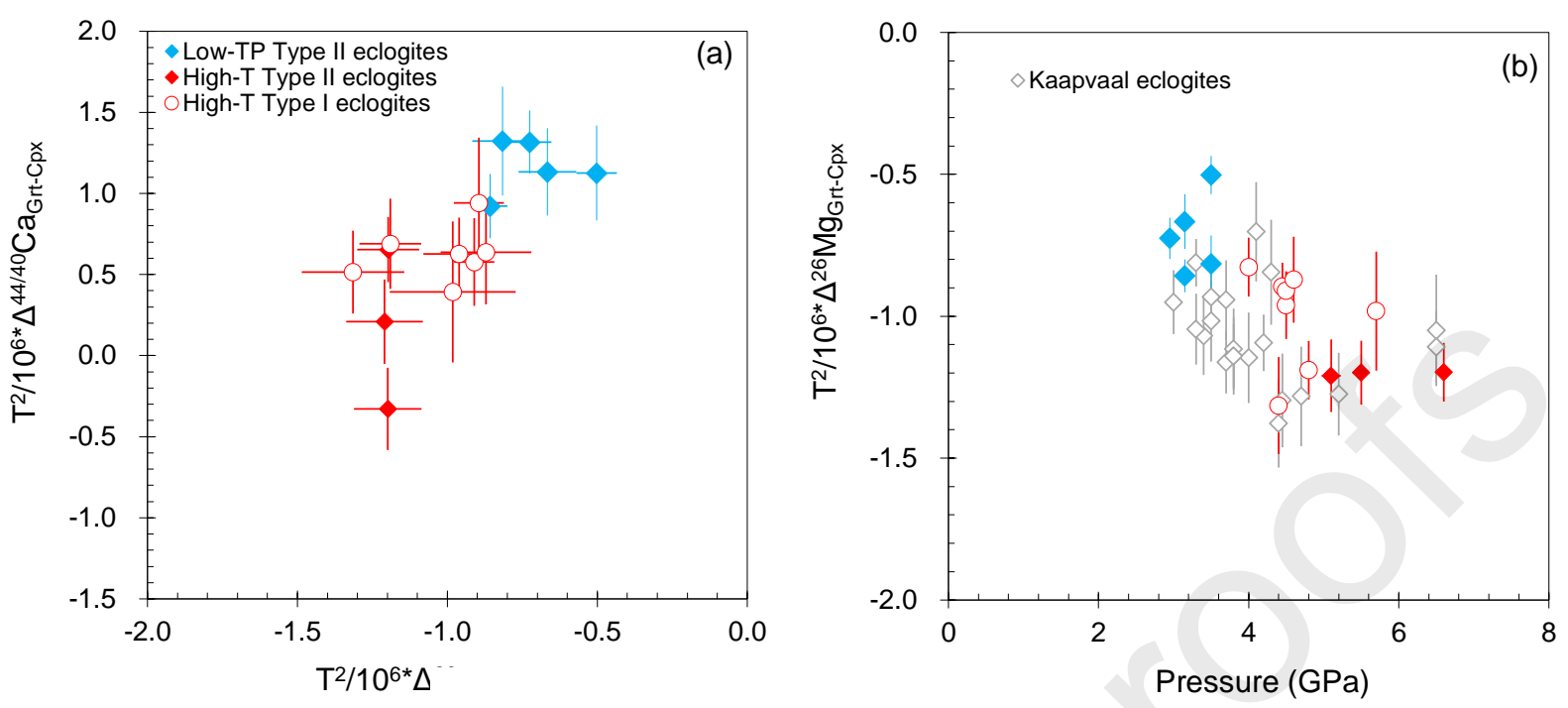
Figure 9

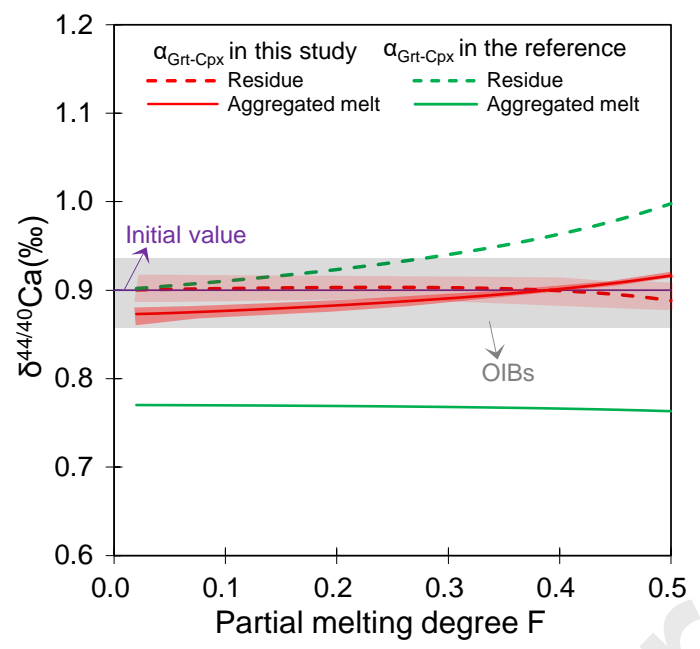

